\title{
Седиментология и геохимия верхнедевонских отложений юго- восточного обрамления Западно-Сибирской геосинеклизы
}

Сараев С. В., Ганашилин А. С.

\begin{abstract}
Аннотация
Охарактеризован верхнедевонский вулканогенно-карбонатно-терригенный комплекс отложений севера Кузнецкого прогиба, погружающийся на севере под мезозойско-кайнозойский чехол Западно-Сибирской геосинеклизы. Анализ седиментологических процессов, характера проявления и специфики состава примесного пирокластического материала, петрографического и химического состава осадочных пород позволяет реконструировать фациальные и геодинамические обстановки. Выявлен преобладающий андезитовый состав тонкой пирокластики при меньшем значении в осадках кислых и основных по составу вулканических компонентов. От раннего франа к фамену, происходит увеличение кислой составляющей примесной пирокластики. Установлены обстановки шельфа и континентального склона Сибирского континента вплоть до его основания. Фациальный анализ фиксирует западное направление склона. Преобладал бассейновый тип отложений, представленный тонко-, мелкозернистыми терригенными породами, тонкообломочными известняками, склоновыми оползневыми брекчиями и олистостромами, турбидитами, «конгломератовидными известняками» (палеосейсмитами). Согласно геохимическим данным палеогеодинамическая обстановка в позднем девоне характеризуется стабильностью. Она соответствовала условиям активной континентальной окраины. Установлен аридный, переходящий в семигумидный тип литогенеза. Морские отложения формировались в окисной обстановке с хорошей аэрацией вод.
\end{abstract}

\section{Ключевые слова:}

Верхний девон, литология, геохимия осадочных пород, палеогеодинамика, Кузнецкий прогиб, Западно-Сибирская геосинеклиза 


\title{
СЕДИМЕНТОЛОГИЯ И ГЕОХИМИЯ ВЕРХНЕДЕВОНСКИХ ОТЛОЖЕНИЙ ЮГО- ВОСТОЧНОГО ОБРАМЛЕНИЯ ЗАПАДНО-СИБИРСКОЙ ГЕОСИНЕКЛИЗЫ
}

\author{
С.В. Сараев, А.С. Ганашилин
}

Институт нефтегазовой геологии и геофизики им. А.А. Трофимука СО РАН, 630090, Новосибирск, просп. Академика Коптюга, 3, Россия

\section{УДК 552.5+551.8:551.734(571.1)}

Охарактеризован верхнедевонский вулканогенно-карбонатно-терригенный комплекс отложений севера Кузнецкого прогиба, погружающийся на севере под мезозойско-кайнозойский чехол Западно-Сибирской геосинеклизы. Анализ седиментологических процессов, характера проявления и специфики состава примесного пирокластического материала, петрографического и химического состава осадочных пород позволяет реконструировать фациальные и геодинамические обстановки. Выявлен преобладающий андезитовый состав тонкой пирокластики при меньшем значении в осадках кислых и основных по составу вулканических компонентов. От раннего франа к фамену, происходит увеличение кислой составляющей примесной пирокластики. Установлены обстановки шельфа и континентального склона Сибирского континента вплоть до его основания. Фациальный анализ фиксирует западное (в современных координатах) направление склона. Преобладал бассейновый тип отложений, представленный тонко-, мелкозернистыми терригенными породами, тонкообломочными известняками, склоновыми оползневыми брекчиями и олистостромами, турбидитами, «конгломератовидными известняками» (палеосейсмитами). Согласно геохимическим данным палеогеодинамическая обстановка в позднем девоне характеризуется стабильностью. Она соответствовала условиям активной континентальной окраины. Установлен аридный, переходящий в семигумидный тип литогенеза. Морские отложения формировались в окисной обстановке с хорошей аэрацией вод.

Верхний девон, литология, геохимия осадочных пород, палеогеодинамика, Кузнецкий прогиб, Западно-Сибирская геосинеклиза.

\section{ВВЕДЕНИЕ}

Выдающийся ученый академик И.М. Губкин был первым среди исследователей, кто в начале 30-х годов прошлого столетия обосновал прогноз о больших перспективах нефтегазоносности мезозоя Западно-Сибирской низменности (3СН). Он также поддерживал перспективность поиска нефти и в палеозое этой территории, опираясь на признаки нефтеносности палеозоя обрамления 3СН, в первую очередь девона на севере Кузбасса [Губкин, 1932]. Выявленные здесь барзасские сапропелиты он сравнил с доманиковыми девонскими сланцами Ухтинского месторождения, западного склона Урала и верхнедевонскими сланцами Чаттануга в составе обширной нефтеносной территории Мидконтинента Северной Америки.

Другой выдающийся геолог-нефтяник академик А.А. Трофимук, также стоящий в ряду первых исследователей Западно-Сибирского нефтегазоносного бассейна, большое значение придавал перспективам нефтегазоносности палеозоя ЗСН, называя его «золотой подложкой» Западно-Сибирской провинции [Трофимук, 1997, стр. 329]. Первое обоснование высоких перспектив нефтегазоносности промежуточного комплекса ЗСН с возрастом от девона до триаса появилось ещё в 1964 году [Трофимук, 1964].

В последние десятилетия в Институте нефтегазовой геологии и геофизики СО РАН благодаря исследованиям большой группы нефтяников, стратиграфов, литологов и геохимиков появилось много работ, посвященных изучению палеозойских отложений приграничных и смежных областей Западно-Сибирской равнины и её горного обрамления 
[Конторович и др., 1999, 2011, 2012, Конторович А.Э., Конторович В.А., 2006; Елкин и др., 1994, 2001, 2003, 2007; Дубатолов, Краснов, 1999, 2000; Запивалов и др., 1996; Сараев и др., 2004, 2009, 2012, 2016, Сараев, 2015; Филиппов и др., 2014; Каныгин и др., 2004; Симонов и др., 2020 и др.]. Использование материалов по обнаженным разрезам палеозоя в горном обрамлении позволяет более полно охарактеризовать эволюцию седиментационных бассейнов на смежной территории Западно-Сибирской геосинеклизы (ЗСГ) в предмезозойское время. В этом отношении наиболее детально изучены максимально представленные в керновом материале на территории ЗСГ верхнедевонские отложения [Елкин и др., 2003, 2007].

На юго-востоке ЗСГ отчетливо выделяется выступ палеозоя (250 х 310 км), представленный структурами Салаира, Колывань-Томской складчатой зоны и Кузнецкого прогиба (рис. 1). В этом выступе отложения верхнего девона наиболее полно вскрываются в естественнвых обнажениях на севере Кузнецкого прогиба. Это позволило поставить следующие задачи: а) продолжить детальное изучение разрезов верхнего девона Кузнецкого прогиба с уточнением литологии карбонатных и терригенных отложений; б) выявить влияние вулканизма на характер отложений; в) на основе использования широко известных геохимических приемов уточненить выводы по фациальным обстановкам, палеогеографии и палеогеодинамике.

Одной из первых работ, посвященных палеогеографическим и геодинамическим реконструкциям в раннем и среднем девоне на рассматриваемой территории, были исследования группы под руководством Е.А. Елкина [Елкин и др., 1994]. В более поздних работах [Елкин и др., 2003, 2007 и др.] временной интервал дополнился материалами по позднему девону, а площадь исследования распространилась на территорию ЗСГ.

Территория Кузнецкого прогиба в девоне входила в Алтае-Салаиро-Кузнецкий седиментационный бассейн [Елкин и др., 1994]. В его пределах выделены три мегазоны морского бассейна: внешняя приконтинентальная, карбонатная платформа и внутренняя (собственно бассейновая). Для интервала раннего девона (лохков, прага) реконструирован режим пассивной окраины, а для эмса и раннего живета, в связи с субдукцией Палеоазиатского океана под Сибирский континент, установлено формирование магматической дуги с последующим смещением её к западу (в современных координатах). В позднем живете и далее в позднем девоне намечено резкое смещение зоны субдукции на запад в сторону океана и раскрытие окраинных морей, в которых наряду с мелководными появляются и глубоководные осадки. Вскрытые в естественных обнажениях Кузнецкого прогиба и в керне скважин на прилегающей территории ЗСГ разрезы верхнего девона демонстрируют фациальный ряд от красноцветных прибрежно-морских и континентальных отложений к морским терригенным, далее к мелководным рифогенным карбонатным и далее к глубоководным тонкотерригенным и кремнистым осадкам [Елкин и др., 2003, 2007]. Колывань-Томская складчатая зона (рис. 1), отделяющая Кузнецкий прогиб от ЗСГ в позднедевонскую эпоху, согласно вписывается в вышеприведенную фациальную зональность, она структурно оформилась только в постдевонское время в конце герцинского орогенеза.

\section{СТРОЕНИЕ РАЗРЕЗОВ, СЕДИМЕНТОЛОГИЯ}

Опорные разрезы франского и фаменского ярусов верхнего девона расположены вблизи северной и северо-западной окраин Кузнецкого прогиба [Типовые разрезы...,1992; Бахарев и др., 2004, Middle-upper..., 2011 и др.]. Наиболее известные и палеонтологически изученные разрезы этого уровня расположены на р. Изылы вблизи д. Вассино (разрез «р. Изылы»), на р.Томи ниже г. Кемерово (разрез «Известковый Завод - Косой Утес»), на левом берегу р. Яя выше бывшего с. Яя-Петропавловское (рис.1).

Разрез «р. Изылы». Разрез по р. Изылы, начинающийся в 0.5 км выше западной окраины с. Вассино Тогучинского района Новосибирской области описывался многими 
исследователями. Среди последних работ необходимо отметить [Типовые разрезы..., 1992, Геологическое строение..., 1999; Middle-upper..., 2011; Язиков и др., 2013; Перегоедов, 2013; Родыгин, 2013, Попов, 2019]. Франский ярус по данным [Язиков и др., 2013] здесь представлен изылинской, вассинской и шубкинской свитами (рис.2).

Изылинская свита. Комплексные палеонтологические данные, полученные в последние годы специалистами ИНГГ СО РАН, позволили установить раннефранский возраст изылинской свиты [Middle-upper..., 2011; Язиков и др., 2013].

В береговых обнажениях р. Изылы вверх по реке в составе изылинской свиты снизу- вверх выделяются четыре пачки (объем пачек см. на рис. 2).

В нижней части разреза свиты (первая и вторая пачки) наблюдается переслаивание алевроаргиллитов, аргиллитов, глинистых биокалькаренитов, мелкозернистых вулканомиктовых песчаников. Часто проявлена градационная слойчатость. Пакеты переслаивания известняков и известково-глинистых пород нередко несут признаки седиментационного будинирования, возникают «конгломератовидные известняки» палеосейсмиты [Seilacher, 1969; Сараев 2012]. Их появление связано с сейсмическими толчками на плоском дне палеобассейнов, при которых происходило фрагментирование, более уплотненных, слаболитифицированных чисто известковых прослоев без значительного перемещения их обломков. Глинистые прослои, как правило, отстающие в своём уплотнении и литификации, преобразовывались в пластичный матрикс.

В калькаренитах наблюдается параллельная, косая слоистость с падением косых серий по азимуту $-330^{\circ} \mathrm{B}$ верхней, большей по объему части свиты (третья и четвертая пачки) вначале преобладают вулканомиктовые песчаники параллельно-, градационнослойчатые с редкими маломощными прослоями песчаных косослойчатых калькаренитов, градационнослойчатых алевроаргиллитов, с включениями галек и гравия андезитов, дацитов, кварца, известняков и силицитов. В самом верху разреза свиты наблюдается чередование преобладающих алевроаргиллитов и мелкозернистых вулканомиктовых песчаников с подчиненными прослоями органогеннообломочных известняков.

В составе неокатанных и полуокатанных обломков песчаной размерности устанавливаются андезиты, дациты, фельзиты, плагиоклазы, редко биотит, глауконит. Содержание кварца изменчиво в разных слоях свиты. Мощность свиты около 80 м.

Вассинская свита отнесена к среднему франу [[Middle-upper..., 2011]]. Она вскрывается на левом берегу р. Изылы, согласно залегая на изылинской свите. В её составе выделяется две пачки. В нижней части она сложена биокалькаренитами с незначительной примесью силикокластики (литокласты андезитов, базальтоидов, изменённого вулканического стекла, более редки плагиоклазы и кварц вулканического облика). В верхней, большей по объему части, преобладают темно-серые, чёрные, иловые, пиритсодержащие известняки без примеси силикокластики, местами с битуминозным запахом, в отдельных прослоях с обилием брахиопод, ругоз, остракод (фации иловых холмов). Мощность свиты около $30 \mathrm{M}$.

Шубкинская свита отнесена к верхнему франу [Middle-upper..., 2011]. Она согласно залегает на вассинской свите и представлена тремя пачками.

В нижней части (около 1 м) свита представлена ритмичным переслаиванием чёрных известково-глинистых, углеродсодержащих, пиритсодержащих тонкослойчатых пород и тёмно-серых до чёрных биокалькаренитов при полном отсутствие примеси силикокластики. Выше (30 м) залегают темно-серые биокалькарениты, кальцрудиты с включениями кремней. В самой верхней части появляются линзовидные мелкие кораллово-строматопоровые биогермы (перемещенные по склону их фрагменты?). Мощность свиты 30 м.

Разрез «Известковый Завод - Косой утес» находится на правом берегу р. Томь начиная от известнякового карьера у пос. Известковый Завод и далее вниз по реке до 
скалы Косой Утес. В строении верхнедевонских отложений (рис. 2) там выделяется три свиты.

Глубокинская свита среднего франа [Middle-upper..., 2011] подразделяется на две пачки. Внизу свита представлена темно-серыми, чёрными известняками (мелкозернистые калькарениты) с редкими мелкими фрагментами одиночных кораллов, строматопорат, ругоз и брахиопод. Вверху (4 м) преобладают конгломератовидные известняки, сложенные лепешковидными, булковидными однородными по составу обломками (седиментационными будинами) темно-серых, чёрных известняков, заключенными в желто-зелёном мергелевом матриксе. В мергелях наблюдается ярко выраженная тонкая параллельная и менее ясно - градационная слойчатость. Конгломератовидные известняки свиты могут рассматриваться как переходные фации от оползневых брекчий к типичным палеосейсмитам. Их возникновение возможно вблизи основания локальной впадины. Примесь силикокластики практически отсутствует. Видимая часть разреза свиты составляет 16 м.

Соломинская свита верхнего франа [Middle-upper..., 2011] подразделяется на 9 пачек. В нижней её части (около 80 м) преобладают криноидные биокалькарениты с редкими прослоями глинистых известняков, брахиоподовых ракушняков, аргиллитов, «конгломератовидных известняков» (палеосейсмитов). В калькаренитах местами наблюдается градационная слойчатость. Примесь песчано-алевритовой силикокластики отсутствует. Выше устанавливается крупнослоевое чередование (27 м) серо-зелёных известковистых алевролитов, аргиллитов, редко тонкозернистых песчаников с линзовидными прослоями брахиоподовых известняков. Неокатанная силикокластика представлена кварцем, полевыми шпатами, изменёнными пепловыми частицами. Самая верхняя части свиты (5 м) сложена зеленовато-серыми мергелями, алевроаргиллитами. В отдельных прослоях отмечается комковатое, брекчиево-оползневое строение. Силикокластика в алевроаргиллитах представлена кварцем, полевыми шпатами, изменёнными, ожелезнёнными вулканогенными литокластами, тонкими чешуйками мусковита. Характерны многочисленные остатки бентосной фауны: криноидеи, мшанки, брахиоподы большей частью в прижизненном положении. Мощность свиты около 110 м.

Пещеркинская свита фамена [Middle-upper..., 2011] подразделяется на 6 пачек (рис. 2). В нижней части (24 м) свита сложена «конгломератовидными известняками» (палеосейсмитами) с прослоями ненарушенных мелко-, грубообломочных и иловых известняков. Алевритовая и песчаная силикокластика отсутствует. Встречаются послойные скопления брахиопод, кораллов, мшанок, криноидей, наутилоидей, гастропод, остракод, редко радиолярий. Наблюдаются выделения кремнистого вещества лепешковидной, округлой формы (до 10 см). Верхняя часть свиты представлена пачкой (13 м), сложенной светло-зелёными монтмориллонит-гидрослюдистыми аргиллитами слабо известковистыми с остатками криноидей, с рассеянными лепешковидными реже изометричными обломками известняков, возникающих при сильном седиментационном будинаже редких известняковых прослоев. Незначительная алевритовая примесь силикокластики представлена кварцем, полевыми шпатами, ожелезнёнными породами. Видимая мощность свиты составляет около 37 м.

Отложения верхнего девона по р. Яя представлены двумя разрезами.

Разрез «р. Яя, левый берег» находится на левом берегу р. Яя в 3,5 км выше бывшего села Яя-Петропавловское в крутой излучине реки. В составе франа здесь выделяются яя-петропавловская и сергиевская свиты (рис. 2). К нижнему франу относится большая часть (1-5 пачки) яя-петропавловской свиты, шестая пачка её принадлежит верхнему франу [Middle-upper..., 2011]. Нижняя, большая часть свиты (1-5 пачки, 137 м) сложена вулканомиктовыми песчаниками средне-, мелкозернистыми с редкими прослоями калькаренитов, аргиллитов и оползневых брекчий с известняковыми обломками и глинисто-известково-песчаным матриксом. Судя по ориентировке косой слоистости, в бассейне существовали течения юго-западного направления (в современных координатах). 
В калькаренитах часто наблюдается обильная (до 50\%) силикокластика и остатки брахиопод, остракод, мшанок, криноидей, кораллов. В кораллах (при изучении в шлифах) отмечается прижизненно внедренная песчаная оскольчатая вулканокластика. Песчаники, как правило, массивные, неслойчатые, лишь изредка градационнослойчатые. На плоскостях наслоения встречается мелкая интерференционная ямчатая рябь волнения. В указанном интервале в составе неокатанных и полуокатанных песчаных обломков присутствуют фельзиты, андезиты, кварц, полевые шпаты, ожелезненные базальтоиды, изменённое вулканическое стекло, хлоритовые породы, туфы, редко глауконит, биотит, мусковит, циркон, турмалин, амфиболы, рудные минералы. При этом в разрезе отдельных пачек (вторая, пятая) наблюдается смена кислой вулканокластики (фельзиты, кварц, ортоклаз) на среднюю-основную (базальтоиды, андезиты, плагиоклазы). Это свидетельствует о резкой смене источника поступающей в осадок «горячей» пирокластики.

Верхняя часть свиты (шестая пачка, 44 м) представлена переслаивающимися известковыми и известково-глинистыми породами. Основная часть пачки сложена чередованием брекчиево-оползневых известняков, биокалькаренитов, глинистых биотурбированных калькаренитов, известково-алеврито-глинистых пород и аргиллитов. Верхняя её часть представлена олистостромовыми оползневыми брекчиями и перекрывающими их известняками и известково-глинистыми породами. Примесь вулканокластики незначительна (ожелезненные андезиты, полевые шпаты, кварц), либо полностью отсутствует (нижняя часть пачки). Аргиллиты, алевро-аргиллиты, слагающие тонкие прослои, обладают параллельной и градационной слойчатостью, содержат в своем составе хлопьевидные ожелезненные частицы, принадлежащие, по-видимому, к тонкой тефре. Общая видимая мощность свиты составляет около 180 м.

Сергиевская свита относится к среднему франу [Middle-upper..., 2011]. В изученном разрезе она представлена пятью пачками (рис.2). В нижней части разреза (первая пачка) свита сложена переслаивающимися вулканомиктовые песчаниками (преобладают), аргиллитами, алевроаргиллитами, а также более редкими прослоями известняков. В песчаниках развивается параллельная и полого-косая слоистость. Полуокатанные обломки представлены преобладающими фельзитами, полевыми шпатами, кварцем, второстепенными - ожелезненными андезитами, базальтоидами, хлоритовыми породами, измененным вулканическим стеклом, туфами, редкими - глауконитом, рудными минералами. Алевроаргиллиты обладают параллельной и градационной слойчатостью.

Вторая пачка сложена красноцветными алевроаргиллитами, аргиллитами, алеврито-известково-глинистыми породами и в верхней части красноцветными вулканомиктовыми мелкозернистыми песчаниками. Полуокатанные и неокатанные обломки представлены фельзитами, кварцем, полевыми шпатами, ожелезненными базальтоидами и более редкими хлоритовыми породами и глауконитом. Выше залегает пакет (34 м), состоящий из трех ритмов (третья, четвертая и пятая пачки). В нижней части каждого ритма находятся гравелито-конгломераты и гравелиты, вверх по разрезу они переходят в песчаники, алевролиты и аргиллиты. Первый снизу ритм относится к красноцветам. Неокатанные, полуокатанные, реже окатанные гравий и галька представлены известняками, песчаниками, красными аргиллитами, фельзитами, яшмой, кварцем, сильно ожелезненными базальтоидами и андезитами. В первом снизу ритме наиболее распространены первые три разновидности галек. В составе вулканических галек преобладают кислые разности пород. Песчаники параллельно-, косослойчатые (направление течений на запад, запад-юго-запад). В составе полуокатанных и неокатанных песчаных обломков также преобладает кислая вулканокластика (фельзиты, кварц, полевые шпаты), к второстепенным обломкам относятся ожелезненные андезиты, базальтоиды, туфы, редко встречаются биотит и глауконит. Видимая мощность свиты около 52 м.

Разрез «р.Яя, ущелье» расположен на левом берегу р. Яя в 2 км выше по течению реки от разреза «р. Яя, левый берег» (рис. 2) и приурочен к каньонообразной промоине, 
ориентированной перпендикулярно долине реки. В разрезе вскрывается кельбесская свита, относящаяся к верхнему франу [Middle-upper..., 2011] и включающая 3 пачки.

В нижней части разреза свиты (первая и вторая пачки, общей мощностью 33 м) свита сложена переслаивающимися тонко-, мелкозернистыми градационнослойчатыми вулканомиктовыми песчаниками, алевролитами, алевроаргиллитами и песчаными биокалькаренитами. Неокатанная и полуокатанная вулканокластика представлена преобладающими фельзитами, хлоритовыми и ожелезнёнными породами, кварцем, более редкими полевыми шпатами, ожелезненными андезитами и глауконитом. В обломках кораллов встречаются окольчатые включения алеврито-песчаной тефры.

Верхняя часть свиты сложена биокалькаренитами часто с крупными фрагментами фауны, брахиоподовыми ракушняками, реже биотурбированными кальцсилтитами. Породы часто массивные, иногда градационнослойчатые. Примесь кислой и андезитовой вулканокластики мелкопесчаной, алевритовой размерности распространена неравномерно: от практически полного её отсутствия до 3\%. В обломках кораллов наблюдается внедренная в скелет оскольчатая тефра мелкопесчаной и алевритовой размерности. Общая мощность свиты $55 \mathrm{м}$.

Пещеркинская свита в изученном разрезе представлена двумя пачками. Первая пачка (25 м) сложена известняками, глинистыми известняками местами с примесью песчано-алевритовой вулканокластики. В нижней половине пачки встречаются прослои оползневых известняковых брекчий. Редко наблюдаются прослои зеленовато-серых известково-глинистых алевролитов и тонкозернистых градационнослойчатых известковистых вулканомиктовых песчаников. Полуокатанная, неокатанная вулканокластика в них представлена полевыми шпатами, кварцем, ожелезненными вулканитами, фельзитами, редко андезитами и биотитом. Вторая пачка (10.5 м) сложена гидрослюдистыми аргиллитами, песчанистыми алевроаргиллитами с мелкими пелециподами. Изредка встречаются тонкие прослои обохренных глинистых известняков с обильными включениями брахиопод. Наряду с неясно выраженной параллельной слойчатостью характерна нормальная градационная слойчатость. Алевритовая и песчаная вулканокластика представлена полуокатанными обломками сильно ожелезненных вулканитов, кварца и полевых шпатов. Мощность свиты около 35 м.

Подонинская свита, относящаяся к фамену (вскрывается самая нижняя её часть), в описываемом разрезе сложена алевроаргиллитами, алевролитами, гидрослюдистыми аргиллитами, тонкозернистыми песчаниками. Встречаются прослои известняков (первые десятки см). Силикокластика представлена неокатанными и полуокатанными обломками сильно ожелезнённых вулканитов, кварца, плагиоклазов, редкими чешуйками мусковита и биотита. Отдельные слои алевролитов сильно обохрены. Видимая мощность свиты 20 м.

\section{ВУЛКАНИЗМ И ОСАДКОНАКОПЛЕНИЕ}

О значительном влиянии вулканизма на осадконакопление Кузнецкого прогиба в верхнем девоне впервые стало известно из работы А.В. Вана [1969]. До этого предполагалось, что эксплозивно-эффузивный тип извержений здесь был сравнительно широко развит только в раннем и среднем девоне. Действующие палеовулканы находились за пределами Кузнецкого прогиба, располагаясь на востоке (в современных координатах) на территории Кузнецкого Алатау и на юге - в Горной Шории. В связи с этим в изученной нами северной окраине прогиба пирокластическая примесь в осадках из-за удаленности от основных вулканических центров характеризуется более тонким структурным составом по сравнению с вулканическим материалом юго-восточных и южных районов, которые, в первую очередь, изучались А.В. Ваном (рис.1). К сожалению, этот исследователь практически не использовал геохимический материал, что снижает достоверность его выводов в отношении состава пирокластики. 
Детальное петрографическое изучение отложений верхнего девона севера Кузнецкого прогиба с оценкой влияния вулканизма, предпринятое нами, позволяют сделать следующие выводы.

Анализ состава и строения изученных разрезов исключает присутствия в них заметных по мощности прослоев собственно туфов. Вместе с тем, в большинстве слоев из описанных разрезов практически всегда фиксируется в изменчивых количествах вулканический обломочный материал псаммитовой, алевритовой, пелитовой, а в конгломератах и псефитовой размерности. Обычно преобладают неокатанные (до оскольчатых) и полуокатанные обломки вулканогенных пород, что позволяет отнести палеоосадки, включающие их, либо к туффитам (чаще известковым), либо к тефроидам (вулканомиктовым песчаникам с частичной обработкой и дифференциацией пирокластики в водной среде).

Вследствие частого преобладания среди пирокластики обломков измененных вулканического стекла и основной массы эффузивов петрографическими методами возможно лишь полуколичественное определение состава пирокластики. Так, по наличию обломков с фельзитовой структурой и сопутствующего кварца (обычно вулканогенного облика), кислых плагиоклазов и калишпатов можно судить о присутствии кислой пирокластики, а обилие обломков изменённой основной массы с пилотакситовой, микролитовой и интерсертальной реликтовыми структурами и соответственно исчезновение или резкое уменьшение количества оскольчатого кварца позволяют утверждать о наличии андезитовой и базальтовой тефры. Прямым свидетельством примеси пирокластики, синхронной осадконакоплению, является присутствие в виде прижизненных вростков оскольчатых её обломков в скелетах кораллов.

\section{ЛИТОХИМИЯ}

Литохимические исследования базируются на 56 силикатных анализах, выполненных рентгенофлюоресцентным методом. Большая часть песчаников на диаграмме Ф. Петтиджона принадлежит грауваккам (рис.За), лишь незначительная часть анализов соответствует литоидным аренитам и аркозам. Составы песчаников по значению гидролизатного модуля ГМ [Юдович, Кетрис, 2000] относятся к силитам (преобладают) и сиаллитам (рис.Зг). (Расшифровка модулей приведена в подписи к рис. Зг).

Согласно [Юдович, Кетрис, 2000, 2010] к признакам, свидетельствующим о присутствии основной по составу пирокластики относятся повышенные содержания силикатного $\mathrm{MgO}$ (>3\%); положительная корреляция ТМ-ЖМ (реликтовая связь, обусловленная эндогенными процессами); негативная корреляция ФМ-НКМ (отражает антагонизм в магматических породах фемических минералов и полевых шпатов); значения ЩМ > 1; повышенные значения ТМ, ЖМ, ФМ. В 5 анализах песчаников из 17 содержание силикатного MgO (с пересчетом анализов на бескарбонатный состав) превышает 3\%, что напрямую свидетельствует о заметной примеси в составе песчаников пирокластики (вулканокластики) основного состава. Анализы с повышенным содержанием силикатного $\mathrm{MgO}$ в песчаниках относятся к среднему франу (сергиевская и глубокинская свиты).

В песчаниках верхнего девона отмечается слабая положительная связь между ТМ и ЖМ и негативная между ФМ и НКМ. Значения титанового модуля ТМ для песчаников из разрезов по р. Яя (свита яя-петропавловская) отвечают в большинстве проб по классификации Я.Э. Юдовича суперзначениям, в то время как в разрезах на р. Томи и на р. Изылы они не превышают нормального уровня. Повышенные значения ТМ для песчаников могут указывать в первую очередь на признаки присутствия в осадках основной пирокластики, хотя этот же эффект возникает при интенсивном перемыве и дифференциации («природном шлиховании») песчаных осадков, содержащих минералы титана [Мигдисов, 1960]. В этих обстоятельствах важно то, что существует первичный исходный источник повышенного титана. 
В песчаниках в большинстве анализов величина фемического модуля ФМ больше 0.1, что указывает на принадлежность отложений к вулканокластическим грауваккам или породам с примесью пирокластики основного состава.

Признаками присутствия кислой пирокластики является [Юдович, Кетрис, 2000]: низкие значения титанового модуля ТМ - меньше 0.02 (нередко ниже 0.005); повышенные, в целом, общая щелочность ОЩ и нормированная щелочность НКМ; отсутствие дефицита $\mathrm{SiO}_{2}$. Известно, что содержание $\mathrm{SiO}_{2}$ в среднем песчанике составляет 78.7\%, в средней граувакке - 66.7\%, в аркозе - 77.1\%, в кварцевом арените - 95\% [Петтиджон и др.,1976]. Использование этих критериев в отложениях верхнего девона севера Кузнецкого прогиба выявляет следующее. Все значения ТМ песчаников в нашей выборке выше порога 0.02. Только одна из исследованных проб имеет повышенную общую щелочность (ОЩ) - 7.56\% (яя-петропавловская свита), медианное значение ОЩ песчаников по всем разрезам составляет 3.35\%. В исследуемых песчаниках верхнего девона содержание $\mathrm{SiO}_{2}$ варьирует в широких пределах - от 44.9 до 70.65\%, медиана составляет 59.04\%, что ниже среднего содержания не только в аркозах, но и в граувакках. Таким образом, литохимический состав песчаников (и алевролитов) верхнего девона севера Кузнецкого прогиба не свидетельствует о присутствии в заметных объемах кислой пирокластики (вулканокластики).

Наибольшие трудности с диагностикой пирокластики (вулканокластики) в осадках возникают, когда она имеет андезитовый состав. В отличие от наиболее близкой к ней по составу базальтовой она не показывает повышенную титанистость и железистость, а в отличие от кислой не имеет повышенной щелочности.

На диаграмме ФМ - НКМ для глинистых пород (рис.Зб) аргиллиты верхнего девона попадают главным образом в V и VI поля соответственно глинистых пород хлоритмонтмориллонит-гидрослюдистого состава и гидрослюдистых глин с примесью мелкоалевритовых частиц полевых шпатов. При этом к полю V тяготеет большая часть проб аргиллитов нижнего, среднего и верхнего франа. Большая часть точек составов аргиллитов фамена принадлежит полю VI, меньшая - полю V. Необходимо отметить, что глины поля VI часто относятся к образованиям кор выветривания аридного климата. По значениям модуля ГМ арггиллиты отвечают сиаллитам (за исключением 2 анализов из 23, относящихся к наиболее зрелым породам - гидролизатам). В отличие от песчаников для аргиллитов практически отсутствуют корреляции между модулями.

C помощью индекса химического выветривания (CIA) и диаграммы A-CN-K [Nesbitt, Young, 1982, Fedo et al., 1995] возможно установление интенсивности поцессов выветривания, зависящих от палеоклимата, а также состава источников сноса (рис.Зв). Значения CIA песчаников изменяются от 40 до 70. Точки составов песчаников на диаграмме (рис.Зв) распадаются на две области. В них по-видимому отражается разное содержание Са-плагиоклазов и калишпатов. Первая отражает тренд изменения осадков с преобладанием примеси пирокластики основного (среднего) состава, вторая - кислого состава.

Значения CIA для верхнедевонских аргиллитов изменяются от 60 до 75, около половины проб отвечает сравнительно интенсивному выветриванию в условиях гумидного и семигумидного климата (значения CIA>70). Пониженные значения CIA в алевритсодержащих аргиллитах обусловлены, возможно, примесью тонкой не успевшей разложиться пирокластики как базальтового, так и более кислого состава. Пирокластика перед захоронением, по-видимому испытывала неравномерное (вследствие эпизодичности её поступления) разложение.

На рис. 4 по соотношению главных литогенных компонентов приведена дискриминантная диаграмма F1-F2 [Roser, Korsch, 1988] для верхнедевонских песчаников северной части Кузнецкого прогиба, позволяющая установить состав источников сноса и примесной пирокластики. Дискриминантные уравнения выглядят следующим образом: $\mathrm{F} 1=\quad-1.773 \mathrm{TiO}_{2}+0.67 \mathrm{Al}_{2} \mathrm{O}_{3}+0.76 \mathrm{Fe}_{2} \mathrm{O}_{3}$ общ- $1.5 \mathrm{MgO}+0.616 \mathrm{CaO}+0.509 \mathrm{Na}_{2} \mathrm{O}-1.224 \mathrm{~K}_{2} \mathrm{O}-9.09$; 
$\mathrm{F} 2=0.445 \mathrm{TiO}_{2}+0.07 \mathrm{Al}_{2} \mathrm{O}_{3}-0.25 \mathrm{Fe}_{2} \mathrm{O}_{3}$ общ- $1.142 \mathrm{MgO}+0.438 \mathrm{CaO}+1.475 \mathrm{Na}_{2} \mathrm{O}+1.426 \mathrm{~K}_{2} \mathrm{O}-6.861$. Состав магматических источников сноса и примесь установленной петрографическими методами синхронной осадконакоплению пирокластики для раннего франа (изылинская, яя-петропавловская свиты) реконструируется для большинства анализов (рис.4) как породы среднего состава (андезиты, диориты), а для среднего франа (три анализа из четырех) как зрелый кварцсодержащий рециклированный материал. Единичные анализы песчаников позднего франа попадают на этой диаграмме в поле кислых магматических пород и зрелых рециклированных песчаников.

\section{ЗАКОНОМЕРНОСТИ РАСПРЕДЕЛЕНИЯ ЭЛЕМЕНТОВ-ПРИМЕСЕЙ, УСЛОВИЯ ОСАДКОНАКОПЛЕНИЯ И ПАЛЕОГЕОДИНАМИЧЕСКИЕ ОБСТАНОВКИ}

Микроэлементный состав пород (Sc, V, Cr, Co, Ni, Zn, Rb, Sr, Y, Zr, Nb, Mo, Ba, La, Ce, Pr, Nd, Sm, Eu, Gd, Tb, Dy, Ho, Er, Tm, Yb Lu, Hf, Ta, Th, U) определялся методом ИСП-МС (34 анализа). На спайдер-диаграмме, нормированной по PAAS (не приведена), устанавливается не всегда согласованное распределение элементов, связанных с повышенным содержанием либо в базитах, либо в гранитоидах, что, по-видимому, связано со смешанным составом примесной пирокластики. Максимальное рассогласование характерно для аргиллитов верхнего франа и фамена. Заметных различий в поведении элементов в различных типах пород и на различных стратиграфических уровнях за исключением подвижных элементов $\mathrm{Sr}, \mathrm{Zn}, \mathrm{Rb}$ и $\mathrm{Ni}$ не отмечается. В распределении редкоземельных элементов (Р3Э) наиболее выражена Eu-аномалия для аргиллитов нижнего и среднего франа.

Состав источников сноса и примесной пирокластики. Преобладание в областях сноса кислых или основных магматических пород может быть установлено по -отношению $\mathrm{La}_{N} / \mathrm{Yb}_{N}$ [Тейлор, МакЛеннан, 1988; Yang et al., 1998]. Пологий наклон кривых Р3Э на диаграммах и отношение $\mathrm{La}_{N} / \mathrm{Yb}_{N}<4$ свидетельствуют о существенном вкладе в петрофонд пород основного состава, при величине этого отношения более 8 предполагается преобладание кислых магматических пород, значение отношения $\mathrm{La}_{\mathrm{N}} / \mathrm{Yb}_{\mathrm{N}}$ $>20$ свидетельствует о господстве в области сноса гранитоидов или гнейсов. Отношение $\mathrm{La}_{N} / \mathrm{Yb}_{N}$ для аргиллитов, алевролитов и песчаников верхнего девона севера Кузнецкого прогиба составляет около 7, что свидетельствует о смешанном составе магматических пород в области выветривания и примеси синхронной пирокластики, либо о преобладании средних по составу магматических пород. Отмечается незначительное увеличение этого отношения вверх по разрезу.

Наличие в отложениях отрицательной Eu-аномалии типично для кислых магматических пород - Eu/Eu*<0.85, в то время как в базальтоидах $\mathrm{Eu} / \mathrm{Eu}^{*}>0.85-0.90$ [Тейлор, Мак-Леннан, 1988, 1991]. Значение $\mathrm{Eu} / \mathrm{Eu}^{*}$ для терригенных пород верхнего девона изученного разреза составляет менее 0.85, находясь вблизи границы, отделяющей основные и кислые породы. Величина $\mathrm{Eu} / \mathrm{Eu}^{*}$ слабо уменьшается снизу-вверх по разрезу, свидетельствуя, как и в случае с отношением $\mathrm{La}_{\mathrm{N}} / \mathrm{Yb}_{\mathrm{N}}$ о возможном увеличении роли кислых магматических пород в области питания от раннего франа к фамену.

Известно также, что содержания и отношения слабоподвижных и близких к ним элементов, имеющих контрастно различную концентрацию в кислых, основных, средних магматических породах и различную степень корреляции между собой, могут использоваться в качестве критериев для установления состава питающих провинций [Балашов, 1976; Langmiur et al.,1978; Taylor, McLennan, 1985, 1991; Wronkiewicz, Condie, 1987, 1990; Condie, 1993; Cullers, 2002; Скляров и др., 2001]. К отношениям элементов, имеющим повышенные значения в кислых магматических породах по сравнению с основными, относятся: Th/Sc, Th/Cr, Th/Co, La/Sc, La/Co, V/Ni, Cr/V, Cr/Zr. В табл. 1 приведены значения отношений элементов для разновидностей магматических пород, рассчитаных согласно их кларков, приведенных в работе [Скляров и др., 2001]), а в табл. 2 
- медианные их значения для пород верхнего девона севера Кузнецкого прогиба. Сопоставление этих величин позволяет сделать следующие выводы.

1 Сравнение отношений элементов в песчаниках и аргиллитах верхнего девона севера Кузнецкого прогиба показало, что устанавливается наибольшая близость этих отношений к андезитам - диоритам (вплоть до совпадения абсолютных их значений). По степени сходства величин отношений они выстраиваются в ряд: Th/Cr, Th/Co, Th/Sc, $\mathrm{La} / \mathrm{Sc}, \mathrm{Cr} / \mathrm{Zr}, \mathrm{La} / \mathrm{Co}$.

2 Сравнение значений в песчаниках и аргиллитах показывает их близость. Повидимому, наряду с другими возможными причинами эта закономерность может быть обусловлена тем, что она возникла в результате поступления в осадок андезитовой пирокластики разной размерности (от пелитовой до алевритовой и песчаной).

3 В общем разрезе от нижнего франа к среднему, верхнему франу и далее к фамену для отношений Th/Cr, Th/Co, Th/Sc, La/Sc, La/Co в аргиллитах наблюдается возрастание этих значений (увеличение кислой составляющей в петрофонде и/или в поступающей пирокластике). В песчаниках (при значительно меньшем аналитическом материале) эта закономерность характерна только для отношений Th/Sc, Th/Cr и Th/Co.

Реконструкция окислительно-восстановительных обстановок седиментации. Обычно в качестве индексов окислительно-восстановительных обстановок придонных вод рассматриваются следующие показатели: степень пиритизации железа осадков (СП), величина «аутигенного» урана (Uaym), концентрация Mn в осадках, а также такие отношения элементов как Mo/Mn, V/Cr, Ni/Co, V/(V+Ni), Sпир/Сорг, U/Th. В аргиллитах нижнего, среднего, верхнего франа и фамена севера Кузнецкого прогиба медианные значения U/Th не поднимаются выше 0.3, V/Cr выше 1.3, Ni/Co выше 2.7, что соответствует обстановкам окисной зоны.

В породах верхнего девона севера Кузнецкого прогиба значения $\mathrm{Mo} / \mathrm{Mn}$ не поднимаются выше 0.003, что соответствует обстановкам с хорошей аэрацией вод [Холодов, Недумов, 2005].

Оценка присутствия в осадках эксгаляционных компонентов. Критическое значение модуля Страхова $(\mathrm{Fe}+\mathrm{Mn}) / \mathrm{Ti}$, при котором устанавливается присутствие эксгалятивного вещества, равно 25 и больше [Страхов, 1976], хотя этот порог в отдельных регионах, по-видимому, может быть снижен до 15 [Стрекопытов и др., 1995].

Согласно полученным данным модуль Страхова в аргиллитах и песчаниках (рассчитывался раздельно) не превышает 11 единиц, что исключает влияние подводных эксгаляций на процессы седиментации в позднедевонском бассейне на территории севера Кузнецкого прогиба.

Индикаторы климатических условий на палеоводосборах седиментационного бассейна. Часть этой проблемы затронута в разделе, посвященному литохимии. В данном разделе ограничимся только использованием параметра SCe/SY - отношения суммы легких Р3Э (La+Ce+Pr+Nd+Sm+Eu) к сумме тяжелых $(\mathrm{Gd}+\mathrm{Tb}+\mathrm{Dy}+\mathrm{Ho}+\mathrm{Er}+\mathrm{Tm}+\mathrm{Yb}+\mathrm{Lu}+\mathrm{Y})$ [Ронов и др., 1972; Балашов, 1976; Шатров, 2004]. Это отношение для различных типов климата принимает следующие значения: <2.5 - аридный; 2.5-4.0 - семигумидныйсемиаридный; >4 - гумидный [Шатров, 2004]. Для верхнего девона севера Кузнецкого прогиба в целом медианное значение этого отношения для аргиллитов составляет 3.01, повышаясь от 2.3 в нижнем фране до 3.01 в среднем фране, 3.24 - в верхнем фране. В фамене в аргиллитах это отношение составляет 3.12, в песчаниках верхнего девона оно равно 3.12. Таким образом, согласно этому критерию климат на территории севера Кузнецкого прогиба в раннем фране был аридным, а в остальное время - семигумидным семиаридным.

Геохимические критерии топофаций седиментационного палеобассейна. Наиболее перспективными критериями, на наш взгляд, являются отношение Zr/Hf, а также величина отрицательной цериевой аномалии (Cе/Ce*). Модуль $\mathrm{Zr} / \mathrm{Hf}$ в прибрежных осадках транстихоокеанского профиля составляет около 33, в пелагических осадках - 40- 
45, а в приспрединговой зоне - 49 [Стрекопытов и др., 1995]. Медианные значения отношения $\mathrm{Zr} / \mathrm{Hf}$ в аргиллитах севера Кузнецкого прогиба практически не отличаются в разрезе от нижнего франа к фамену (от 36 до 38), несколько превышая значения, характерные для прибрежных отложений. В песчаниках это отношение (от 38 до 42) приближается к величине, характерной для пелагических осадков.

Величина отрицательной цериевой аномалии $(\mathrm{Ce} / \mathrm{Ce} *)$ в породах верхнего девона севера Кузбасса также может быть использована в качестве индикатора глубинности бассейна и насыщенности морских вод кислородом [Murray et al., 1990; Мигдисов и др. 1998]. В породах верхнего девона она выражена слабо (медиана - 0.95) и отвечает параметрам окраинно-континентальных обстановок.

Реконструкция палеогеодинамических обстановок. Незначительные изменения отношения $\mathrm{Cr} / \mathrm{Th}$ в изученном разрезе свидетельствуют об определенном постоянстве палеотектонической обстановки [Condie, Wronkiewicz, 1990]. На геодинамической диаграмме Б.Розера и Р.Корша [Roser, Korsch, 1986] верхнедевонские песчаники и алевролиты севера Кузбасса попадают в поле активных континентальных окраин и островных дуг (рис.5a). Соотношение оксидов K2O/Na2O и (Fe2O3+MgO) в песчаниках севера Кузнецкого прогиба на диаграмме М.Бхатиа [Bhatia, 1983] близко песчаникам приконтинентальных зрелых островных дуг (рис. 5б). Использование диаграмм М.Бхатиа и K.Крука [Bhatia, Crook, 1986], основанных на соотношениях La, Y, Sc, Cr, Th, Co, Zr (не приведены) дают подобные же результаты - точки составов концентрируются в поле приконтинентальных зрелых островных дуг.

\section{ОБСУЖДЕНИЕ РЕЗУЛЬТАТОВ И ВЫВОДЫ}

К общим чертам строения свит нижнего франа, относится появление в песчаниках текстурных последовательностей А.Боума, включающих градационную, параллельную и косую слоистости, что указывает на распространенность среди осадков турбидитов. Наиболее часто они встречаются в разрезе изылинской свиты. Турбидитные потоки имеют западную направленность (в современных координатах). Вместе с тем, среди отложений нижнего франа встречаются образования оползневых брекчий, мелких олистостром и характерных «конгломератовидных известняков» - палеосейсмитов. Если первые отвечали обстановкам шельфового склона, то вторые характерны уже бассейновым условиям, так как их возникновение исключает обстановки склона. Палеосейсмиты широко развиты в разрезе «р. Изылы» и отсутствуют в разрезе «р. Яя». Учитывая распространение редко встречаемых шлейфовых фаций передового склона рифа, сменяющих их тонкообломочных илов бассейнового типа, оползневых брекчий, палеосейсмитов, турбидитов, ориентировку турбидитных течений и географическое расположение разрезов, можно сделать вывод, что увеличение глубинности бассейна и направление материкового склона и было ориентировано на запад, юго-запад (в современных координатах) (от р. Яя в сторону р. Изылы) (рис. 1). В районе р.Изылы, по-видимому, располагалось основание склона, где пространственно близко встречаются оползневые брекчии, олистостромы, турбидиты и палеосейсмиты.

Более мелководные нижнефранские отложения разреза по р. Яя были подвержены интенсивной биотурбации. В разрезе по р. Изылы признаки биотурбации практически отсутствуют. В обоих изученных разрезах нижнего франа в составе песчаников и силикатной примеси в известняках в качестве обломков преобладает вулканический материал. Его трудно разделить на собственно пирокластический («горячая пирокластика») и вулканомиктовый [Хворова, 1983; Петрографический..., 2009] (возникший при разрушении субсинхронных осадконакоплению вулканических построек). Преобладание в изученном разрезе среди вулканических обломков измененного вулканического стекла и основной массы эффузивов не предполагает дальнего переноса этого реакционноспособного материала. Вместе с тем, постоянное присутствие в 
обломках неокатанных (вплоть до оскольчатых) зерен указывает на заметное участие в осадконакоплении «горячей пирокластики». В статье для обозначения всех подобных отложений использован термин «вулканомиктовые песчаники» за неимением термина, объединяющего трудно различимые туфопесчаники, тефроидные песчаники и граувакки.

На основе петрографических данных в изученных разрезах полуколичественно оценивалось содержание обломков кислой и средней-основной пирокластики (преобладающие, второстепенные и редкие обломки). Наиболее контрастно это соотношение проявилось в яя-петропавловской свите, по-видимому, вследствие наибольшей близости её изученного разреза к вулканическим центрам. Так, в самой нижней (первой) её пачке песчаная тефра имеет смешанный состав, во второй пачке наблюдается снизу - вверх изменение от преобладания кислой тефры внизу до преобладания обломков андезитов и базальтоидов вверху. Третья и четвертая пачки характеризуются кислой пирокластикой и, наконец, в пятой пачке наблюдается переход от кислой внизу к средней-основной вверху.

На западе района в изылинской свите в разрезе по р. Изылы в нижней пачке также наблюдается смесь тефры кислого и среднего состава, во второй и третьей наблюдается преобладание кислой пирокластики, а в верхней четвертой пачке отмечается смешанный состав (андезиты - фельзиты). Таким образом, в грубых чертах тренд изменения состава в обоих свитах совпадает, хотя в изылинском разрезе, удаленном на 160 км от разреза по р. Яя степень смешения пирокластики разного состава значительно больше. Явное преобладание продуктов кислого вулканизма по петрографическим данным наблюдается только в средней части разреза нижнего франа.

Характерной особенностью распространения пирокластики является и тот факт, что в разрезе по р. Яя она часто фиксируется прижизненно внедренной в скелет кораллов (захват её в процессе их роста), чего не наблюдалось в разрезе по р. Изылы.

Отложения среднего франа представлены вассинской свитой (разрез «р. Изылы»), глубокинской (пожарищевской) свитой (разрез «Известковый Завод - Косой Утес»). В разрезе «р.Яя, левый берег» к среднему франу отнесена шестая пачка свиты яяпетропавловская и сергиевская свита [Middle-Upper...,2011]. Отложения вассинской и глубокинской свит представлены исключительно тонкообломочными известняками, в то время как среднефранский разрез по р. Яя имеет сложное строение. В нем в нижней части (шестая пачка свиты яя-петропавловская) наблюдается переслаивание карбонатных и терригенных, терригенно-карбонатных пород, а в верхней половине (сергиевская свита) резко преобладают терригенные отложения с появлением красноцветов и крупнозернистых песчаников, гравелитов, гравелито-конгломератов. Известняки вассинской, глубокинской свит и в меньшей степени карбонатные породы шестой пачки яя-петропавловской свиты достаточно близки между собой. Это типичные бассейновые иловые или тонкозернистые осадки, как правило, массивные, неслоистые. Окраска пород часто темно-серая до черной, местами появляется седиментационный пирит. При этом признаки глубоководности нарастают с востока на запад в сторону р. Изылы. В глубокинской свите только в самой верхней части разреза в качестве примеси появляется глинистый материал, что приводит к появлению градационнослойчатых пород, а также типичных палеосейсмитов и оползневых брекчий. В более восточном разрезе по р. Яя палеосейсмиты исчезают и их сменяют опозневые брекчии, мелкие олистостромы, что указывает на господство склоновых фаций. Становится очевидным, что рельеф седиментационного среднефранского бассейна унаследуется от существовавшего в раннем фране.

Если придерживаться схемы корреляции, предложенной в работе [MiddleUpper...,2011], то в верхней части среднего франа известны своеобразные отложения сергиевской свиты, связанные, по-видимому, с появлением среди выдержанных бассейновых отложений осадков турбидитовых каналов. Характер отложений резко изменяется. На смену иловым известнякам приходит чередование разнозернистых 
песчаников, гравелитов, конгломерато-гравелитов, алероаргиллитов, аргиллитов, алеврито-известково-глинистых пород, редко маломощных прослоев известняков. Нередко образуются грубоградационные пакеты с постепенным переходом снизу- вверх от конгломерато-гравелитов через грубозернистые песчаники и алевролиты к аргиллитам. Судя по составу псефитовых обломков в 1-4 пачках и их слабой окатанности гравелитоконгломераты относятся к внутриформационному типу. Обломки представлены песчаниками, известняками, аргиллитами (в том числе и красноцветными), а также неопределимыми сильно ожелезненными вулканитами. Последние, вероятно, могут относиться к перемытым базальтоидам и андезитам. На это, кроме ожелезненности, косвенно указывает отсутствие кварцевых обломков в конгломерато-гравелитах. В верхней, пятой пачке состав гравийно-галечных обломков резко изменяется - начинают преобладать фельзиты и связанные с ними яшмы, кварц. Яркой особенностью этого разреза становится появление многочисленных прослоев красноцветов, связанное с размывом кор выветривания по вулканитам на прилегающей суше. По красноцветам на постседиментационной стадии развиваются зоны зеленоцветной окраски (зоны оглеения), к ним привязаны горизонты известковых конкреций.

Потоки терригенного материала в среднем фране по сравнению с ранним франом не изменили своего направления, оставаясь в западных, юго-западных румбах (в современных координатах), что свидетельствует о стабильности континентального склона.

Вулканическая составляющая в отложениях вассинской, глубокинской свит и самой верхнней части яя-петропавловской свиты практически незаметна. Незначительная её примесь представлена редкими обломками базальтоидов и андезитов.

В сергиевской свите в нижней её части (первая и вторая пачки) обломки фельзитов, кварца и полевых шпатов преобладают над андезитами и базальтоидами. В третьей пачке в составе гальки вулканитов преобладают полностью ожелезненные вулканиты, а среди алевроаргиллитов - красноцветы. В песчаниках содержатся полуокатанные и неокатанные обломки наиболее распространенных фельзитов, кварца, полевых шпатов, биотита и только среди второстепенных обломков - ожелезненные базальтоиды, андезиты. В четвертой пачке в составе галек наиболее распространены известняки, широко развиты фельзиты, к второстепенным относятся базальтоиды и андезиты. В песчаниках преобладают неокатанные и полуокатанные обломки фельзитов, кварца и полевых шпатов, к второстепенные принадлежат ожелезненные базальтоиды и андезиты. В верхней пятой пачке среди вулканокластов как в песчаниках, так и в гравийно-галечной фракции резко преобладают фельзиты, яшмы и кварц. Таким образом, в разрезе сергиевской свиты отмечается снизу-вверх нарастающее влияние кислого вулканизма.

Верхний фран представлен шубкинской свитой (разрез «р. Изылы»), соломинской свитой (разрез «Известковый Завод- Косой Утес»), кельбесской свитой (разрез «р.Яя, ущелье»). Отложения шубкинской свиты соответствуют обстановкам сравнительно глубоководного бассейна, в самой нижней части отвечающим условиям замедленной седиментации с обогащенностью органическим веществом и седиментационным пиритом. Терригенное вещество присутствует только в виде тонкой глинистой фракции. Позднее в бассейн поступал главным образом тонко-, мелкообломочный известковый материал без примеси как песчано-алевритовой, так и глинистой составляющей.

Соломинская свита в нижней своей части содержит переслаивающиеся прослои как хорошо промытых биокалькаренитов, так и мергелей, аргиллитов. Поскольку эти осадки накапливались в бассейновой достаточно глубоководной обстановке с плоским дном, то широко были распространены «конгломератовидные известняки» - палеосейсмиты. Им изредка сопутствовали прослои глинисто-карбонатных турбидитов. В верхней части свиты в отдельных пакетах переслаивания подобного состава появляются брекчиево-оползневые прослои, свидетельствующие о начавшемся процессе усложнения подводного рельефа.

Кельбесская свита в нижней своей половине сложена преобладающими песчаниками, а вверху - известняками. В песчаниках местам появляется параллельная, 
градационная слойчатость (штормовые турбидиты?). Градационная слойчатость характерна и для некоторых прослоев калькаренитов в верхней части свиты.

В разрезах верхнего франа по р. Изылы и на р. Томи (шубкинская и соломинская свиты) влияние вулканизма на осадконакопление практически незаметно. Лишь в верхней половине соломинской свиты появляется силикокластика, представленная главным образом кварцем и полевыми шпатами. Она может отвечать, как кислой тефре, так и слабому фоновому терригенному потоку, поступающему из области питания на континенте. В отличие от этого в кельбесской свите на востоке исследуемого района в песчаниках и в силикокластической примеси в известняках преобладают неокатанные и полуокатанные обломки фельзитов, кварца, в значительно меньшей степени андезитов и сильно ожелезненных пород (возможно, базальтоидов).

Согласно [Middle-Upper...,2011] к фамену относятся пещеркинская свита (разрез «Известковый Завод-Косой Утес»), а также пещеркинская и подонинская свиты в разрезе «р. Яя, ущелье».

В отложениях пещеркинской свиты на западе (разрез «Известковый Завод-Косой Утес») широко рапространены палеосейсмиты, возникшие по первичным переслаивающимся известковым и известково-глинистым осадкам, что указывает на типично бассейновые фации.

Северо-восточнее в разрезе по р. Яя в пещеркинской свите отложения подобного состава вследствие расположения их на материковом склоне при палеосейсмических толчках преобразуются в прослои оползневых брекчий и мелких олистостром. В этом же разрезе встречаются прослои штормовых (?) турбидитов.

Подонинская свита сложена преобладающими алевроаргиллитами, аргиллитами с прослоями плохо сортированных плохо промытых обломочных известняков.

В отложениях пещеркинской свиты на западе исследовнного района по р. Томи примесь силикокластики в известняках практически отсутствует. Незначительное её количество представлено кварцем, полевыми шпатами, возможно оно обусловлено фоновым терригенным потоком.

В разрезе пещеркинской свиты северо-восточнее (разрез «р.Яя, ущелье») содержание примеси обломков вулканических пород несколько больше. Наряду с кварцем и полевыми шпатами присутствуют фельзиты и обломки неопределимых ожелезненных вулканических пород (базальтоидов?).

О составе источников сноса и составе пирокластики, как показано выше, свидетельствуют не только петрографические данные, но и результаты, полученные с помощью геохимических материалов. Полученные выводы не всегда однозначны. Так, в определенной части проб песчаников содержания силикатного $\mathrm{MgO}$, превышающие 3\%, указывают на примесь базальтоидной пирокластики. Положительная корреляция между ТМ и ЖМ и негативная между ФМ и НКМ, высокие величины ФМ в песчаниках, значения ТМ выше порога 0.02 вместе с «дефицитом» кварца и граувакковый тип песчаников - всё это свидетельствует о преобладании в примесной пирокластике и в источниках питания среднего и основного материала над кислым. Такому выводу не противоречат данные диаграммы ФМ-НКМ (рис. Зб), где в составе глинистой фракции реконструируются монтмориллонит и хлорит. Вместе с тем, резкая изменчивость ЩМ и в отдельных случаях повышенная общая щелочность могут свидетельствовать об определенной доле кислых пород в петрофонде и примеси пирокластики кислого состава.

Литохимическая диаграмма F1-F2 для песчаников (рис. 4) указывает на преобладание в раннем фране в составе пород в области сноса и в составе примесной пирокластики андезитов, диоритов, для среднего франа реконструируется зрелый кварцсодержащий рециклированный материал, редкие анализы песчаников позднего франа попадают в поля кислых и средних пород и в поле кварцсодержащего рециклированного материала. Значения параметров $\mathrm{La}_{\mathrm{N}} / \mathrm{Yb}_{\mathrm{N}}$ и $\mathrm{Eu} / \mathrm{Eu}^{*}$ свидетельствуют о смешанном (основном-кислом) составе магматических пород в области сноса и примесной 
пирокластики, либо о проеобладании средних по составу магматических пород. Отмечается постепенное изменение этих отношений в сторону увеличения доли кислых пород на временном отрезке от раннего франа до фамена. Сравнение отношений элементов Th, Sc, Co, La, V, Ni, Cr, Zr в песчаниках и аргиллитах, рассмотренное выше, показало, что устанавливается наибольшая близость их к андезитам-диоритам. В аргиллитах наблюдается возрастание их значений от раннего франа к среднему, позднему франу и далее к фамену, что соответствует увеличению кислой составляющей в петрофонде и в поступающей пирокластике.

Интенсивность химического выветривания в области сноса в первую очередь зависит от палеоклимата. Судя по значениям СIA от 60 до 75 (рис. Зв), около половины проб аргиллитов верхнего девона соответствует обстановкам со сравнительно интенсивным выветриванием в условиях гумидного, семигумидного климата (CIA $>70)$. Значения CIA меньше 70 могут быть связаны как с изменением климата в сторону его аридизации, так и, возможно, за счет выпавшей тонкой свежей пирокластики, не испытавшей континентального выветривания. Согласно критерия SCe/SY, рассчитанному для аргиллитов, климат на территории севера Кузнецкого прогиба в раннем фране был аридным, а в остальное время семигумидным. Составы аргиллитов в основной своей части соответствуют сиаллитам, и только две пробы относятся к максимально высокозрелым в химическом отношении гидролизатам.

Использование большого арсенала геохимических приемов по установлению окислительно-восстановительных обстановок в изученном позднедевонском седиментационном бассейне позволяет сделать вывод, что господствовали обстановки окисной зоны с хорошей аэрацией вод.

Согласно геохимических критериев топофаций седиментационных палеобассейнов ( $\left.\mathrm{Zr} / \mathrm{Hf}, \mathrm{Ce} / \mathrm{Ce}{ }^{*}\right)$ отложения верхнего девона накапливались в окраинно-континентальных обстановках. Достаточно стабильные значения отношения $\mathrm{Cr} / \mathrm{Th}$ свидетельствуют об определенной выдержанности палеотектонической обстановки в позднем девоне. Использование широко известных геодинамических диаграмм Б.Розера, Р.Корша, М.Бхатиа, К. Крука показывает, что песчаники верхнего девона севера Кузнецкого прогиба сформировались в обстановке активной континентальной окраины и зрелых приконтинентальных островных дуг.

Авторы признательны д.г.м.н. Н.В. Сенникову за ценные конструктивные замечания и рекомендации.

Работа выполнена при финаисовой поддержке проекта ФНИ № 0331-2019-0021 «Основные седиментационные и постседиментационные процессы и закономерности их эволюции в протерозойских и фанерозойских осадочных бассейнах Сибири».

\section{ЗАКЛЮЧЕНИЕ}

Для характеристики позднедевонского седиментационного бассейна на территории севера Кузнецкого бассейна использован комплексный подход с привлечением материалов как детального седиментологического изучения опорных разрезов, так и широко известных геохимических методов оценки обстановок осадконакопления и палеогеодинамических параметров. Основные результаты этого анализа сводятся к следующему.

1 В составе вулканокластики (и примесной пирокластики) изученных разрезов в целом преобладал андезитовый материал, при меньшей распространенности кислых и основных компонентов. От нижнего франа к фамену происходило постепенное увеличение присутствия в осадках кислого вулканического материала.

2 Преобладал склоновый и бассейновый тип отложений, представленный тонко-, мелкозернистыми вулканомиктовыми и обломочными карбонатными породами с широким 
распространением оползневых брекчий, турбидитов (в т.ч. редких каналитов), а у начала бассейновой равнины - своеобразных карбонатно-глинистых палеосейсмитов.

3 Установлены обстановки шельфа Сибирского континента и его континентального склона (до начала континентального подножья включительно). Направление склона западное (в современных координатах).шлей

4 По геохимическим данным реконструируется геодинамическая обстановка активной континентальной окраины и зрелых приконтинентальных островных дуг, достаточно выдержанная в течении франа-фамена.

5 В позднедевонском седиментационном бассейне господствовали окисные фации с хорошей аэрацией вод. На прилегающей части континента в раннем фране преобладал аридный климат, который в дальнейшем до фамена включительно сменился на семигумидный.

\section{ЛИТЕРАТУРА}

Балашов Ю.А.Геохимия редкоземельных элементов. М., Наука, 1976,268 с.

Бахарев Н.К., Сенников Н.В., Елкин Е.А., Изох Н.Г., Алексеенко Ф.Ф., Обут О.Т., Родина О.Ф., Сараев С.В., Батурина Т.П., Киприянова Т.П., Тимохина И.Г., Язиков Ф.Ю. Ключевые разрезы девона Рудного Алтая, Салаира и Кузбасса Новосибирск, Изд. СО РАН, 2004, 105 c.

Ван А.В. Верхнедевонские вулканокластические породы Кузнецкого прогиба // Продукты эксплозивного вулканизма в осадочных толщах Сибири. Новосибирск СНИИГГиМС, 1969, с.28-48.

Геологическая карта СССР N-(44), 45 (Новосибирск), м-б: 1:1000000, Мингео СССР, ВСЕГЕИ, 1987

Геологическое строение и полезные ископаемые Западной Сибири. Том 1 / Под ред. А.В. Каныгина, В.Г. Свиридова. Новосибирск, Изд. СО РАН НИЦ ОИГГМ, 1999, 230с.

Губкин И.М. Горючие ископаемые Кузбасса (1932), Избранные труды, т.2, М., 1953, Изд. АН СССР, с. 324-340.

Дубатолов В.Н., Краснов В.И. Фаменский этап в эволюции географических обстановок сибирских морей // Геология и геофизика, 2000, т.41, №2, с.239-254.

Дубатолов В.Н., Краснов В.И. Палеоландшафты раннедевонских морей в Сибири // Стратиграфия. Геологическая корреляция // 1999, т.7, №3, с.95-109.

Елкин Е.А., Сенников Н.В., Буслов М.М., Язиков А.Ю., Грацианова Р.Т., Бахарев Н.К. Палеогеографические реконструкции западной части Алтае-Саянской области в ордовике, силуре и девоне и их геодинамическая интерпретация // Геология и геофизика, 1994, т. 35, №7-8, с.118-143.

Елкин Е.А., Каштанов В.А., Конторович А.Э., Коровников И.В., Кринин В.А., Лучинина В.А., Сараев С.В., Тищенко В.М., Филиппов Ю.Ф., Хоменко А.В. Схема стратиграфии кембрийских отложений приенисейской части Западной Сибири // Геология и геофизика, 2001, т.42, №7, с. 1015-1027.

Елкин Е.А., Бахарев Н.К., Изох Н.Г., Кирда Н П., Клец А.Г., Конторович В.А. Обут O.T., Тимохина И.Г. Палеогеографические обстановки в позднем девоне на территории Западно-Сибирской равнины и её горного обрамления // Геология и геофизика, 2003, т.44, № 1-2, с. 172-182.

Елкин Е.А., Конторович А.Э., Бахарев Н.К., Беляев С.Ю., Варламов А.И., Изох Н.Г, Каныгин А.В., Каштанов В.А., Кирда Н.П., Клец А.Г., Конторович В.А., Краснов В.И., Кринин В.А., Моисеев С.А., Обут О.Т., Сараев С.В., Сенников Н.В., Тищенко В.М., Филиппов Ю.Ф., Хоменко А.В., Хромых В.Г. Палеозойские фациальные мегазоны в структуре фундамента Западно-Сибирской геосинеклизы // Геология и геофизика, 2007, т.48, №6, с.633-650. 
Калугин А.С. Вулканические пеплы и пепловые туфы // Продукты эксплозивного вулканизма в осадочных толщах Сибири. Новосибирск СНИИГГиМС, 1969, с.5-21.

Каныгин А.В., Сараев С.В., Бахарев Н.К., Беляев С.Ю., Брехунцов А.М., Дещеня Н.П., Клец А.Г., Хромых В.Г., Фомин А.Н. Палеозой Щучьинского выступа: модель геологического строения островодужных комплексов в фундаменте Западно-Сибирской геосинеклизы // Геология и геофизика, 2004, т.45, №1, с. 59-78.

Конторович А.Э., Сараев С.В., Казанский А.Ю., Каштанов В.А., Конторович В.А., Пономарчук В.А., Тищенко В.М., Филиппов Ю.Ф. Новый терригенно-вулканогенный разрез кембрия и положение западной границы Сибирской платформы // Геология и геофизика, 1999а, т.40, №7, с.1022-1031.

Конторович А.Э., Костырева Е.А., Сараев С.В., Меленевский В.Н., Фомин А.Н. Геохимия органического вещества кембрия Предъенисейской субпровинции (по результатам бурения скважин Восток-1 и Восток-3) // Геология и геофизика, 2011, т. 52 №6, с. 737-750.

Конторович В.А., Конторович А.Э. Геологическое строение докембрийскопалеозойских платформенных отложений в юго-восточных районах Западной Сибири // Отечественная геология, 2006, № 6, с. 62-70.

Конторович А.Э., Конторович В.А., Коровников И.В., Сараев С.В., Сенников Н.В., Филиппов Ю.Ф., Варламов А.И., Ефимов А.С., Филипцов Ю.А., Постников А.А., Терлеев А.А., Карлова Г.А., Наговицин К.Е., Токарев Д.А., Батурина Т.П., Губин И.А., Кочнев Б.Б., Новожилова Н.В., Лучинина В.А. Разрез кембрия в восточной части Западно-Сибирской геосинеклизы (по результатам бурения параметрической скважины Восток-4) // Геология и геофизика, 2012, т.53, №10, с. 1273-1284.

Мигдисов А.А., Ярошевский А.А, Бреданова Н.В. Отражение в осадочном чехле платформ изменений состава внешних оболочек Земли // Глобальные изменения природной среды. Новосибирск, Изд-во СО РАН НИЦ ОИГГМ, 1998, с. 167-176.

Перегоедов Л.Г. Брахиоподы изылинских и вассинских слоев среднего-верхнего девона стратотипического разреза по р. Изылы // Региональная стратиграфия позднего докембрия и палеозоя Сибири. Сб. научн. тр. Под ред. В.И. Краснова. Новосибирск: СНИИГГиМС, 2013, с. 156-167.

Попов Б.М. Биостратиграфические данные по остракодам из опорных разрезов среднего и верхнего девона окраин Кузнецкого бассейна (юго-восток Западной Сибири) // Геология и минерально-сырьевые ресурсы Сибири, 2019, № 2, с. 3-15.

Родыгин С.Ф. Конодонты пограничных образований среднего и верхнего девона южной Сибири // Региональная стратиграфия позднего докембрия и палеозоя Сибири. Сб. научн. тр. Под ред. В.И. Краснова. Новосибирск: СНИИГГиМС, 2013, с. 136-140.

Ронов А.Б., Балашов Ю.А., Гирин Ю.П. Закономерности распределения редкоземельных элементов в осадочной оболочке и в земной коре // Геохимия, 1972, №12, c. $1483-1513$.

Сараев С.В., Хоменко А.В., Батурина Т.П., Карлова Г.А., Кринин В.А. Венд и кембрий юго-востока Западной Сибири: стратиграфия, седиментология, палеогеография // Геология, геофизика и разработка нефтяных и газовых месторождений, 2004, №1, с.7-18.

Сараев С.В., Батурина Т.П., Пономарчук В.А., Травин А.В. Пермотриасовые вулканиты Колтогорско-Уренгойского рифта Западно-Сибирской геосинеклизы // Геология и геофизика, 2009, т.50, №1, С.4-20.

Сараев С.В., Батурина Т.П, Бахарев Н.К., Изох Н.Г. Сенников Н.В. Среднепозднедевонские островодужные вулканогенно-осадочные комплексы северозападной части Рудного Алтая // Геология и геофизика, 2012, т. 53, №10, с.1285-1303.

Сараев С.В. Палеосейсмиты в обстановках карбонатной седиментации // Материалы Всероссийского литологического совещания, Санкт-Петербург, 25-29 сентября 2012 г., том 1, Санкт-Петербург, 2012, с.247-249. 
Сараев С.В. Литолого-фациальная характеристика усольской свиты (нижний кембрий) и её возрастных аналогов Предъенисейского осадочного бассейна Западной Сибири // Геология и геофизика, 2015, т.56, №6, с.1173-1188.

Сараев С.В., Батурина Т.П., Медведев А.Я., Травин А.В. Каменноугольные отложения в фундаменте юго-запада Западно-Сибирской геосинеклизы (Курганская область) // Геология и геофизика, 2016, т.57, №8, с.1455-1476.

Симонов В.А., Конторович В.А., Котляров А.В., Сараев С.В., Филиппов Ю.Ф., Ступаков С.И. Условия развития раннепалеозойского базальтового и пикритового магматизма Западной Сибири // Геология и геофизика, 2020, т.61, №11, с. 1476-1498.

Скляров Е.В., Гладкочуб Д.П., Донская Т.В., Иванов А.В., Летникова Е.Ф., Миронов А.Г., Бараш И.Г., Буланов В.А., Сизых А.И. Интерпретация геохимических данных. М., Интермет инжиниринг, 2001, 288 с.

Страхов Н.М. Проблемы геохимии современного океанского литогенеза. М., Наука, 1976, 299 с.

Стрекопытов С.В., Дубинин А.В., Волков И.И. Поведение РЗЭ, Циркония и гафния в осадках и конкрециях транстихоокеанского профиля // Геохимия, 1995, №7, с.985-997.

Типовые разрезы пограничных отложений среднего и верхнего девона, франского и фаменского ярусов окраин Кузнецкого бассейна / Под ред. В.И. Краснова, М.А. Ржонсницкой, Я.М. Гутака. Новосибирск, Тр. СНИИГГиМС, 1992, 187 с. 37-44.

Трофимук А.А. Нефть и природный газ Сибири // Вестник АН СССР, 1964, № 6, с.

Трофимук А.А. Сорок лет борения за развитие нефтегазодобывающей промышленности Сибири. Новосибирск, Изд. СО РАН НИЦ ОИГГМ, 1997, 370 с.

Тейлор С.Р., Мак-Леннан С.М. Континентальная кора: её состав и эволюция. Пер. с англ. М., Мир, 1988, 384 с.

Филиппов Ю.Ф., Сараев С.В., Коровников И.В. Стратиграфия и корреляция кембрийских отложений Предъенисейского осадочного бассейна Западной Сибири // Геология и геофизика, 2014, т.55, №5-6, с. 891-905.

Хворова И.В. Вулканогенно-осадочные породы // Справочник по литологии, М. Недра, 1983, с.232-244.

Холодов В.Н., Недумов Р.И. О применении молибденового модуля к реконструкции газового состава вод Атлантики // Доклады АН, 2005, т. 400, №2, с.250-253.

Шатров В.А. Редкоземельные элементы как индикаторы условий образования метаосадочных пород нижнего протерозоя // Доклады РАН, 2004, т. 397, №3, с. 396-399.

Юдович Я.Э., Кетрис М.П. Основы литохимии. Санкт-Петербург, Наука, 2000, 480с.

Юдович Я.Э., Кетрис М.П. Геохимические и минералогические индикаторы вулканогенных продуктов в осадочных толщах. Екатеринбург, РИО УрО РАН, 2010, 412с.

Язиков А.Ю., Бахарев Н.К., Изох Н.Г., Сараев С.В., Родина О.А., Щербаненко Т.А. Био- и литостратиграфическая характеристика изылинского горизонта (девон, западная окраина Кузнецкого бассейна) // Региональная стратиграфия позднего докембрия и палеозоя Сибири. Сб. научн. тр. Под ред. В.И. Краснова. Новосибирск: СНИИГГиМС, 2013, с. $146-155$.

Condie K.C. Chemical composition and evolution of the upper continental crust: contrasting results from surface simples and shales // Chem. Geol., 1993, v. 104, p. 1-37.

Condie K.C., Wronkiewicz D.J. Cr/Th ratio in Precambrian pelites from Kaapvaal Craton as an index of craton evolution // Earth Planet. Sci. Lett., 1990, v. 97, 256-267.

Jones B., Manning D.A.C. Comparison of geochemical indices, used for the interpretation of paleoredox conditions in ancient mudstones // Chem. Geol., 1994, v.111, №1-4, p. 111-129.

Langmiur C.H., Vocke R.D., Hanson G.H., Hart S.R. A general mixing equation with applications to Icelandic basalts // Earth and Planet Sci. Let. 1978, v. 37, p. 380-392. 
Le Maitre R.W. The chemical variability of some common igneous rocks. // J. Petrol., 1976, v.17, №4, p. 589-637.

Middle-Upper Devonian and Lower Carboniferous Biostratigraphy of Kusnetsk Basin. Field Excursion Guidebook International Conference «Bioctratigraphy, paleogeography and events in Devonian and Lower Carboniferous» (SDS/IGCP 596 joint fields meeting) // (Authors: N.K. Bakharev, N.G. Isokh, A.Yu. Yazikov, T.A. Shcherbanenko, S.A. Anastasieva, O.T. Obut, S.V/ Saraev, L.G. Peregoedov, V.G. Khromykh, O.A. Rodina, I.G. Timokhina, T.P. Kipriyanova). Novosibirsk, July 20-August 10, 2011, Novosibirsk: Publishing House of SB RAS, 2011, 98 p.

Murray R. W, Buchholtz ten Brink M.R., Jones D. L., Gerlach D.C., Russ P.G. Rare earth elements as indicators of different marine depositional environments in chert and shale // Geology, 1990, v. 18, p.268-271.

Nesbitt Y.W., Young G.M. Early Proterozoic climates and plate motions inferred from major element chemistry of lutites // Nature, 1982, v. 299, p. 715-717.

Seilacher A. Fault-graded beds interpreted as seismites // Sedimentology. 1969 v.13, p. 155-159.

Taylor S. R., McLennan S.M. The Continental Crust: Its Composition and Evolution. Blackwell, Oxford, 1985, 312 p.

Taylor S. R., McLennan S.M. Sedimentary rocks and crustal evolution: tectonic setting and secular trends // J. Geol, 1991, v. 99, p. 1-21.

Wronkiewicz D.J., Condie K.C. Geochemistry and mineralogy of sediments from the Ventersdorp and Transvaal Supergroups, South Africa: cratonic evolution during the early Proterozoic // Geochim. Cosmochim. Acta, 1990, v. 54, p. 343-354. 
Рис. 1. Схема тектонического районирования по [Геологическая карта..., 1987] с изменениями и расположение изученных разрезов.

1- разрезы, изученные авторами: 1- р. Изылы, ниже и выше плотины, 2- р. Томь на участке от пос. Известковый Завод до Косого Утеса, 3- р. Яя выше с. Яя-Петропавловское; 2-разрезы, изученные А.В. Ваном [Ван, 1969]: 1- Ермаковская опорная скважина 1-Р, 2-р.Томь у пос. Симоново, 3 - р.Томь выше устья р. Бельсу, 4 - р. Кондома выше пос. Кузедеево; 3геологические границы, 4- глубинные разломы. Темно-серым цветом выделен Кузнецкий прогиб, светло-серым - ЗСГ, бесцветным - другие структуры на их границах.

\section{Рис. 2. Разрезы верхнего девона севера Кузнецкого прогиба.}

1- конгломерат, 2- гравийно-галечный конгломерат, 3- гравелит, 4-песчаник, 5-гравелитистый песчаник, 6- известковый песчаник, 7- алевролит, 8- алевроаргиллит, 9-песчанистый алевролит, 10- аргиллит, 11- известковый аргиллит, 12- мергель, 13- известняк, 14песчанистый известняк, 15- песчаный известняк, 16- сильно известковый песчаник, 17глинистый известняк, 18- алевритовый известняк, 19- известняк с включением тефры, 20оползневой известняк, 21- конгломератовидный известняк (палеосейсмит), 22- известняк окремненный, 23- оолитовый известняк, 24- известняк углеродсодержащий, 25олистостромовая брекчия (с указанием состава обломков), 26-конкреции, 27красноцветность, 28- пропуск в наблюдениях.

Рис. 3. Петрохимические диаграммы для верхнедевонских пород севера Кузнецкого прогиба. а- петрохимическая классификация песчаников по [Pettijohn et al., 1972]; бмодульная диаграмма для аргиллитов ФМ - НКМ по [Юдович, Кетрис, 2000]; в- диаграмма A-CN-K $\left(\mathrm{Al}_{2} \mathrm{O}_{3}-\left(\mathrm{CaO}+\mathrm{Na}_{2} \mathrm{O}\right)-\mathrm{K}_{2} \mathrm{O}\right)$ в мол. количествах по [Nesbitt, Young, 1982]; г - модульная диаграмма ГМ - ФМ - ТМ - НКМ по [Юдович, Кетрис, 2000] для песчаников. Песчаники: 1нижнего франа, 2- среднего франа, 3- верхнего франа, 4- фамена; аргиллиты: 5- нижнего франа, 6- среднего франа, 7- верхнего франа, 8- фамена, 9- средний состав верхней континентальной коры [Taylor, McLennan, 1988], 10- средний базальт [Le Maitre, 1976], 11средний гранит [Le Maitre, 1976].

Здесь и в тексте: ФМ - фемический модуль $\left(\mathrm{Fe}_{2} \mathrm{O}_{3}+\mathrm{FeO}+\mathrm{MnO}+\mathrm{MgO}\right) / \mathrm{SiO}_{2} ; \mathrm{HKM}$ - модуль нормированной щелочности $\left(\mathrm{Na}_{2} \mathrm{O}+\mathrm{K}_{2} \mathrm{O}\right) / \mathrm{Al}_{2} \mathrm{O}_{3} ; \quad \Gamma \mathrm{M}-$ гидролизатный модуль $\left(\mathrm{TiO}_{2}+\mathrm{Al}_{2} \mathrm{O}_{3}+\mathrm{Fe}_{2} \mathrm{O}_{3}+\mathrm{MnO}\right) / \mathrm{SiO}_{2} ; \mathrm{TM}$ - титановый модуль $\mathrm{TiO}_{2} / \mathrm{Al}_{2} \mathrm{O}_{3} ;$ ЩМ - щелочной модуль $\mathrm{Na}_{2} \mathrm{O} / \mathrm{K}_{2} \mathrm{O} ; \mathrm{KM}$ - железный модуль $\left(\mathrm{Fe}_{2} \mathrm{O}_{3}+\mathrm{FeO}+\mathrm{MnO}\right) /\left(\mathrm{TiO}_{2}+\mathrm{Al}_{2} \mathrm{O}_{3}\right) ;$ ОЩ - общая щелочность $\mathrm{Na}_{2} \mathrm{O}+\mathrm{K}_{2} \mathrm{O}$.

Рис. 4. Дискриминационная диаграмма F1-F2 по [Roser, Korsch, 1988], характеризующая состав пород области сноса и примесной пирокластики для верхнедевонских песчаников севера Кузнецкого прогиба. Поля Р1, Р2 и Р3 отвечают обломочному материалу, по составу приближающегося к исходным породам соответственно основного, среднего и кислого состава. Поле P4 отвечает зрелому рециклированному осадочному материалу. Звездочки - составы магматических пород: Б - базальта, А - андезита, Д - дацита, Рд - риодацита, Г, Рл - гранита, риолита. Условные обозначения на рис. 3.

Рис. 5. Дискриминационные геодинамические диаграммы для верхнедевонских песчаников и алевролитов севера Кузнецкого прогиба: а по [Roser, Korsch, 1986], б по [Bhatia, 1983]. А - океанические (юные) островные дуги, В -приконтинентальные (зрелые) островные дуги, C - активная континентальная окраина, D - пассивная континентальная окраина.

Условные обозначения на рис. 3 
Табл. 1. Средние значения отношений элементов в главных типах магматических пород по [Скляров и др.2001]

\begin{tabular}{l|c|c|c|c|c|c}
\hline $\begin{array}{r}\text { Отношения } \\
\text { элементов }\end{array}$ & Th/Sc & Th/Cr & Th/Co & La/Sc & La/Co & Cr/Zr \\
\hline Породы & 0,11 & 0,02 & 0,07 & 0,57 & 0,35 & 1,38 \\
Граниты & 2,77 & 3,21 & 18 & 7,38 & 48 & 0,03 \\
Гранодиориты, дациты & 0,76 & 0,45 & 0,13 & 3,92 & 0,65 & 0,16 \\
Диориты, андезиты & 0,33 & 0,11 & 0,43 & 1,17 & 1,5 & 0,32
\end{tabular}


Табл. 2. Медианные значения отношений элементов для пород верхнего девона севера Кузнецкого прогиба

\begin{tabular}{|c|c|c|c|c|c|c|c|}
\hline $\begin{array}{l}\text { 量 } \\
\text { on } \\
\text { 吕 }\end{array}$ & $\begin{array}{c}\text { стратиграфический } \\
\text { уровень (кол-во проб) }\end{array}$ & $\mathrm{Th} / \mathrm{Sc}$ & $\mathrm{Th} / \mathrm{Cr}$ & Th/Co & $\mathrm{La} / \mathrm{Sc}$ & $\mathrm{La} / \mathrm{Co}$ & $\mathrm{Cr} / \mathrm{Zr}$ \\
\hline \multirow{5}{*}{ 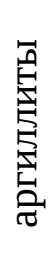 } & Dз (23) & 0,56 & 0,11 & 0,65 & 1,81 & 2,14 & 0,51 \\
\hline & $F_{1}(6)$ & 0,38 & 0,11 & 0,43 & 1,04 & 1,16 & 0,47 \\
\hline & $\mathrm{F}_{2}(4)$ & 0,40 & 0,08 & 0,48 & 1,41 & 1,84 & 0,57 \\
\hline & F3 (9) & 0,63 & 0,12 & 1,24 & 2,22 & 2,74 & 0,52 \\
\hline & Fm (4) & 0,71 & 0,14 & 1,00 & 2,27 & 3,01 & 0,47 \\
\hline \multirow{4}{*}{ 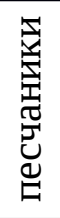 } & D3 (8) & 0,42 & 0,07 & 0,46 & 2,79 & 2,42 & 0,55 \\
\hline & $\mathrm{F}_{1}(5)$ & 0,35 & 0,05 & 0,31 & 2,35 & 1,80 & 0,59 \\
\hline & $\mathrm{F}_{2}(1)$ & 0,42 & 0,06 & 0,44 & 6,10 & 6,32 & 0,73 \\
\hline & $\mathrm{F}_{3}(2)$ & 1,07 & 0,12 & 1,12 & 3,58 & 3,84 & 0,45 \\
\hline$\frac{\partial}{\tilde{z}}$ & F3 (3) & 0,42 & 0,12 & 0,49 & 1,26 & 1,37 & 0,50 \\
\hline
\end{tabular}




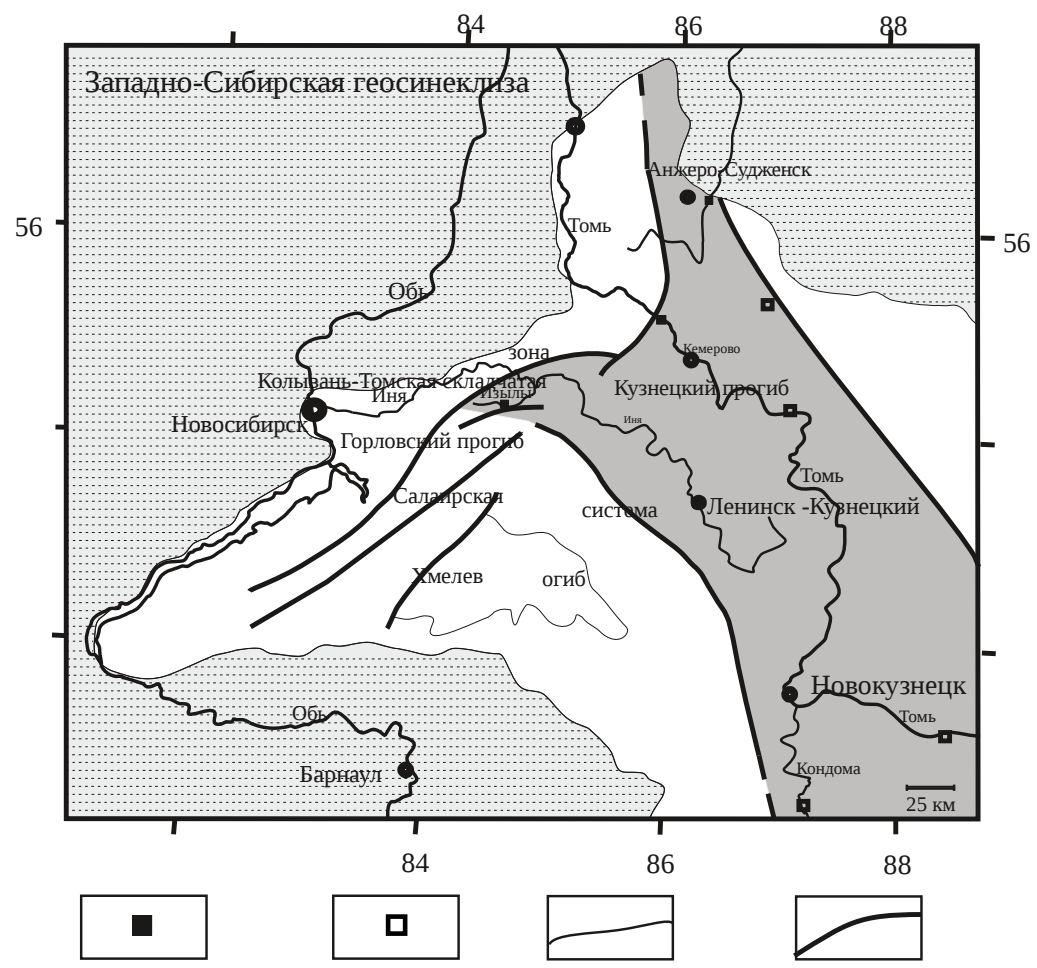


р.Изылы

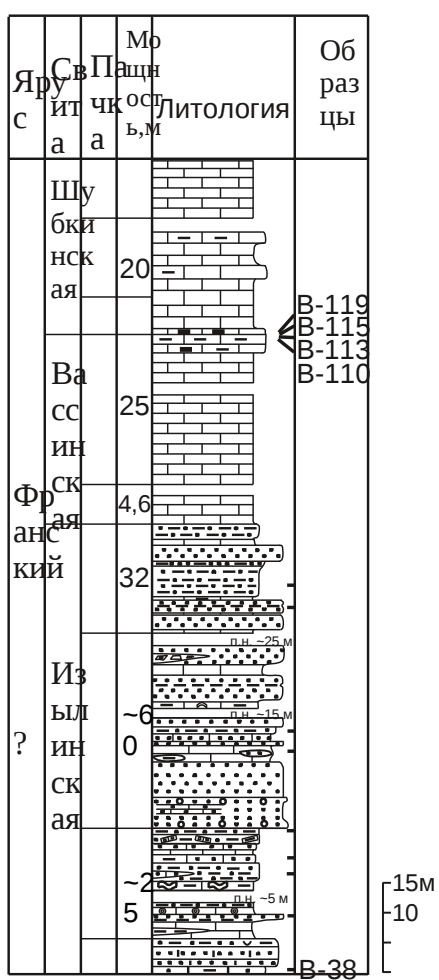

р.Томь

(с.Известковый завод-

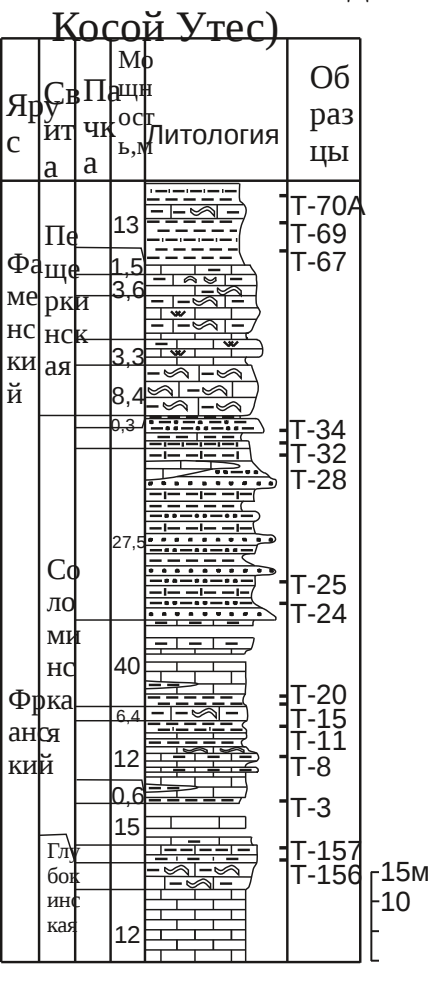

(левый берег
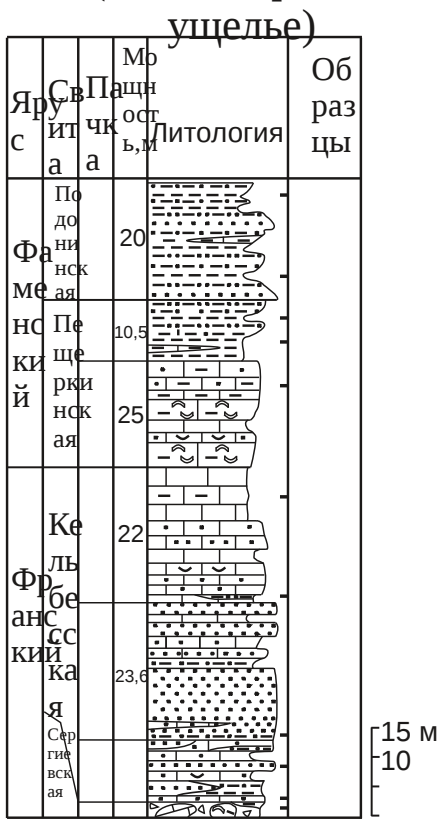

р.Яя

(левый берег выше с,Яя-Петропавдовское)

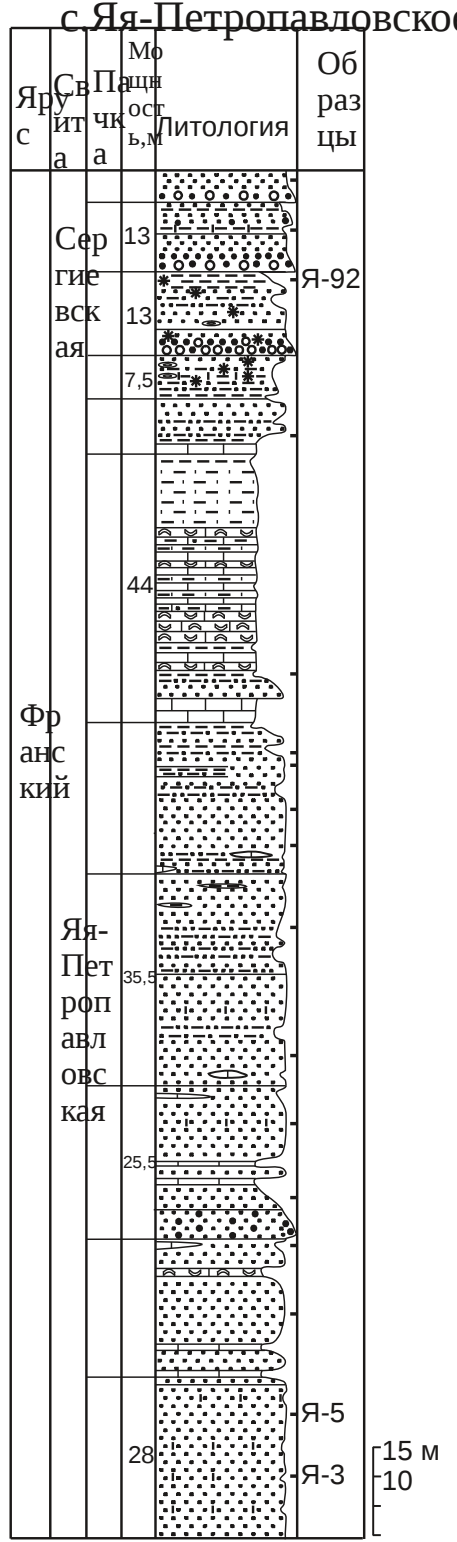

Условные обозначения:

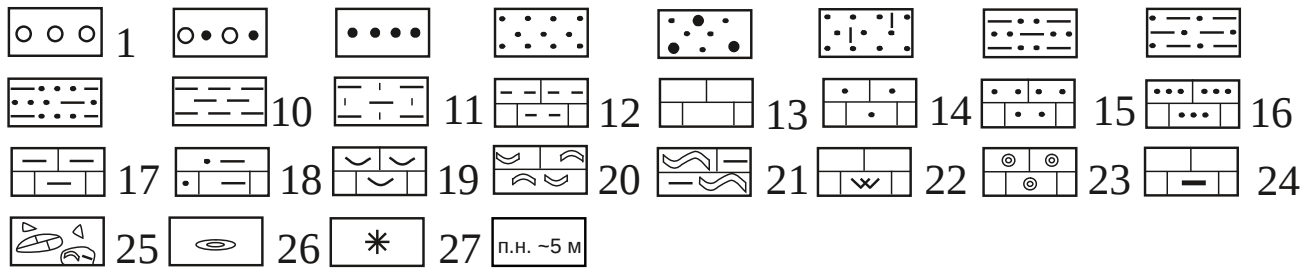



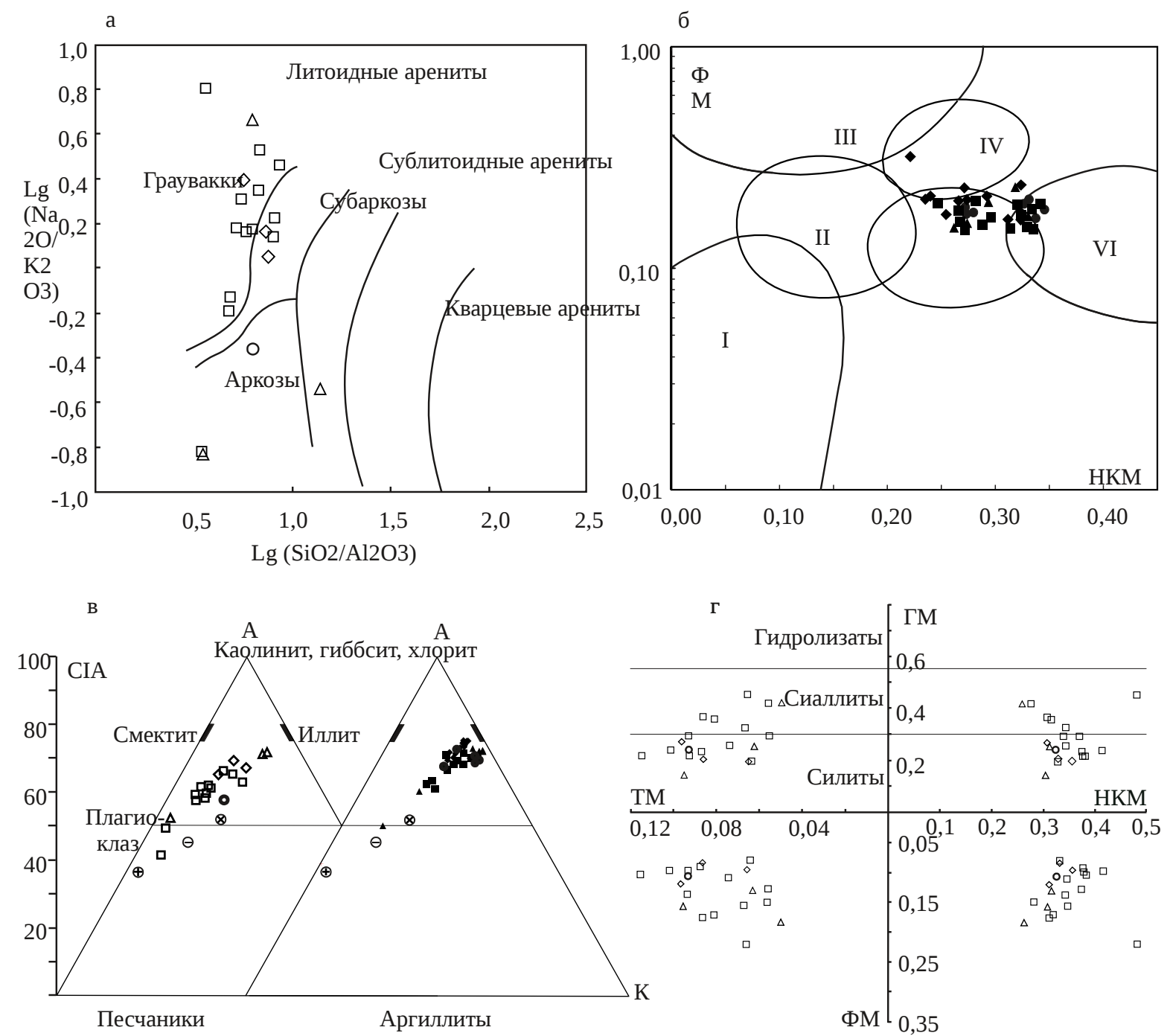

口
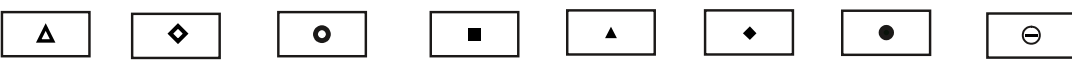
11 


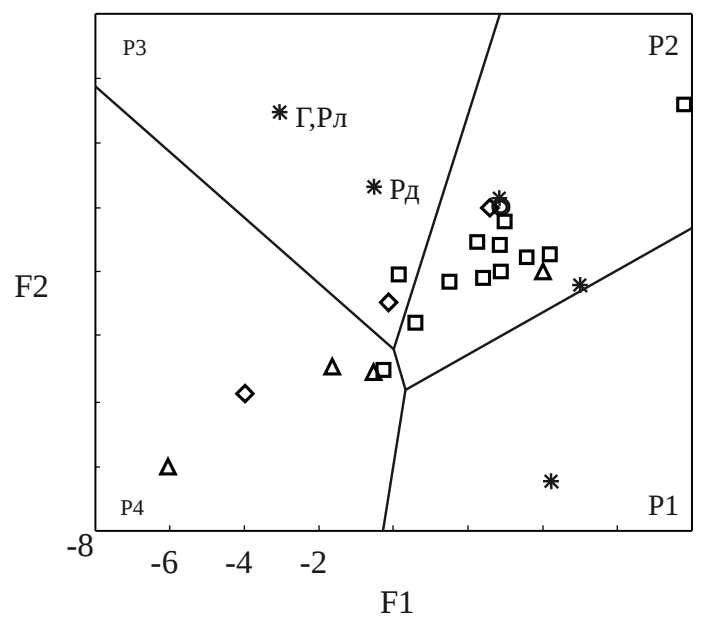



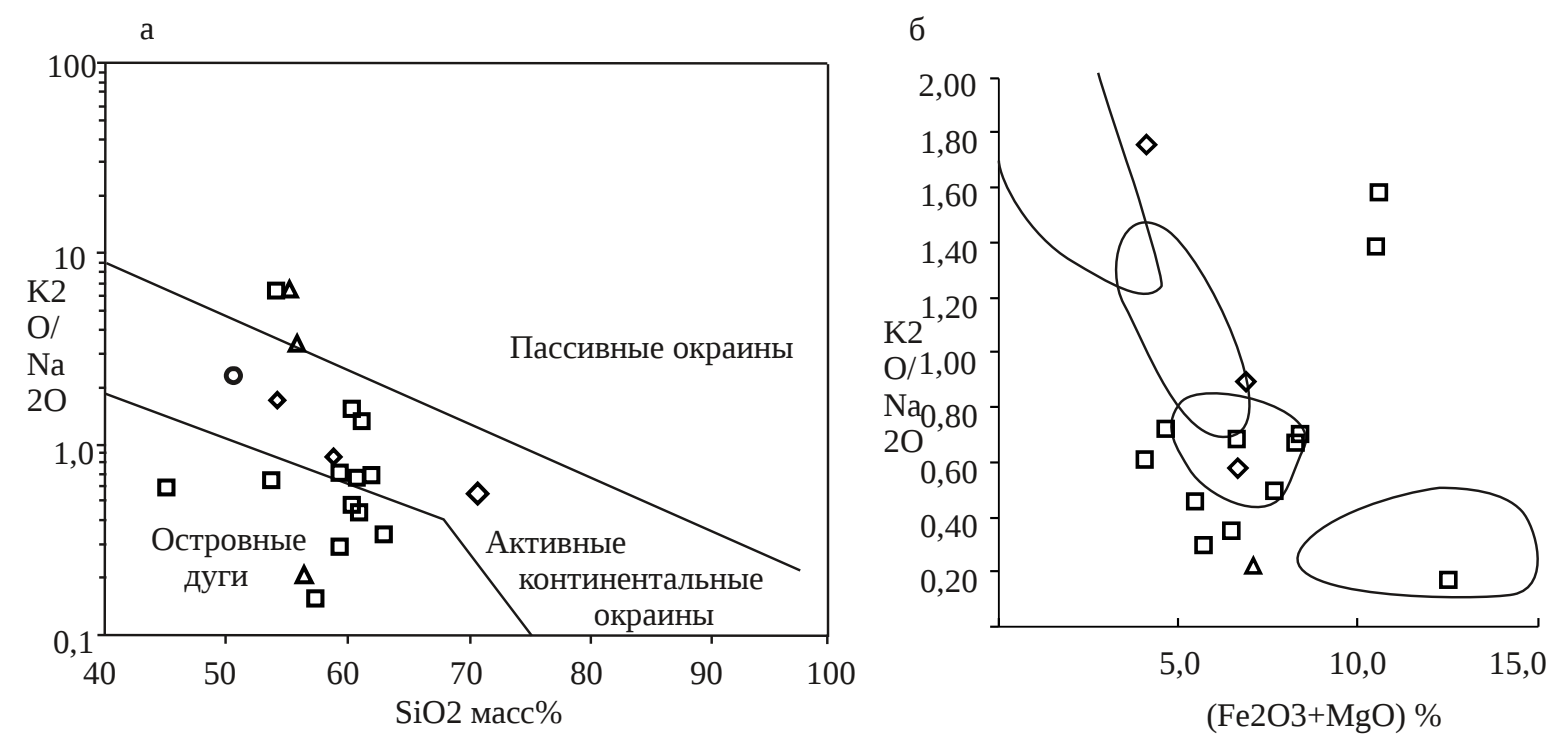